Check for updates

Cite this: RSC Adv., 2017, 7, 44410

Received 29th June 2017

Accepted 8th September 2017

DOI: $10.1039 / c 7 r a 07225 b$

rsc.li/rsc-advances

\section{Internal asymmetric induction by the C-6 substituent on the oxidation reaction of interglycosidic sulfur atom of thiodisaccharides $\uparrow$}

\author{
J. P. Colomer, ${ }^{* a}$ A. B. Peñéñory $\mathbb{D D}^{a}$ and O. Varela (iD *bc
}

Since the enantio or diastereoselective preparation of sulfoxides is a current challenge, we explore the possibility of inducing diastereoselectivity in the oxidation of the sulfur atom of thiodisaccharides, according to their substitution patterns. Thus, a series of 3 -deoxy-4-S-( $\beta$-D-glucopyranosyl)-4-thio- $\beta$-Dxylo-hexopyranoside derivatives, with different substituents at $\mathrm{C}-6(\mathrm{OH}, \mathrm{OAc}$ or OTBS) of the reducing end, have been synthesized and treated with $m$-CPBA for the oxidation of the sulfur atom at $C-4$, which is vicinal to $\mathrm{C}-6$. The absolute configuration at the sulfur stereocenter of the resulting sulfoxides was established taking into account shielding/deshielding anisotropic effects of the $\mathrm{S}=\mathrm{O}$ bond on the chemical shift of the NMR signals of selected protons, in the most populated syn $\phi / s y n \psi$ conformation of the thiodisaccharide $S$-oxides. The OAC and OTBS derivatives afforded diastereomeric mixtures of $R$ and $S$ sulfoxides in a similar ratio (1.4:1 and 1.6:1, respectively). In contrast, the oxidation of thiodisaccharide with a free hydroxyl group at C-6 was completely diastereoselective in favor of the $R$ sulfoxide. The influence of the thiodisaccharide C- 6 substituent on the stereochemical course of the oxidation is discussed.

\section{Introduction}

Numerous organic molecules containing sulfoxide functionality show a wide range of interesting biological activities. Many compounds of this type are employed as pharmaceuticals (e.g., sulforaphane, ${ }^{1}$ esomeprazole, ${ }^{2}$ and armodafinil ${ }^{3}$ ) and present a specific configuration at the sulfur stereocenter, which is crucial to generate the desired biological effect. In addition, enantiomerically pure sulfoxides are employed as powerful chiral auxiliaries, ligands or catalysts in asymmetric

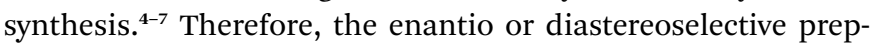
aration of sulfoxides is a current challenge for synthetic organic chemists. In this regard, a number of procedures for the diastereoselective or enantioselective (including enzymes or microorganisms) sulfoxidations have been reported. ${ }^{8-11}$

The oxidation of the sulfur atom of thioglycosides usually affords diastereomeric mixtures of glycoside sulfoxides, and the

${ }^{a}$ Instituto de Investigaciones en Fisico-Quimica de Córdoba - Universidad Nacional de Córdoba (INFIQC-UNC-CONICET), Facultad de Ciencias Quimicas, Departamento de Química Orgánica, Edificio de Ciencias 2, Ciudad Universitaria, CP5016 - Córdoba, Argentina. E-mail: juanpablo@fcq.unc.edu.ar

${ }^{b}$ Universidad de Buenos Aires, Facultad de Ciencias Exactas y Naturales, Departamento de Química Orgánica, Pabellón 2, Ciudad Universitaria, C1428EHA Buenos Aires, Argentina. E-mail: varela@qo.fcen.uba.ar

${ }^{c}$ Consejo Nacional de Investigaciones Científicas y Técnicas (CONICET)-UBA, Centro de Investigación en Hidratos de Carbono (CIHIDECAR), Buenos Aires, Argentina

$\dagger$ Electronic supplementary information (ESI) available. See DOI: 10.1039/c7ra07225b diastereoselectivity relies on the solvent, the temperature and the structure and substitution of the starting $S$-glycoside. ${ }^{12}$ In some particular cases, high diastereoselectivities in the oxidation of thioglycosides have been achieved. ${ }^{13}$ Witczak and coworkers ${ }^{14}$ reported the oxidation of thiodisaccharides to sulfoxides or sulfones, derivatives that inhibit the proliferation of selected murine and human tumor cell lines. However, the sulfoxides were obtained as diastereomeric mixtures and the absolute configuration of the SO group has not been established.

In connection with our work on the synthesis of thiodisaccharides and their inhibitory activity of specific glycosidases, ${ }^{15-19}$ we have studied the oxidation of these substrates to their respective diastereomeric sulfoxides. These compounds could be successfully separated in many cases and the absolute configuration of the sulfur stereocenter was determined by a procedure developed by us..$^{20,21}$ This procedure is based on NMR techniques and takes into account anisotropic effects of the $S=O$ group. Our results were in agreement with those obtained using other methodologies employed to assign the sulfur absolute configuration of glycosyl sulfoxides. ${ }^{13,22-24}$

The diastereomers $R_{\mathrm{S}}$ and $S_{\mathrm{S}}$ of sugar sulfoxides are hydrolyzed with different kinetics by acids or glycosidases. ${ }^{12}$ Thus, we have prepared and assigned the configuration of sulfur for both isomers of benzyl 3-deoxy-4-S-( $\beta$-D-galactopyranosyl)-4-thio- $\beta$-Dthreo-pentopyranoside $S$-oxides, which showed to be competitive inhibitors of the $\beta$-galactosidase from Escherichia coli. ${ }^{20,21}$ The key structural features of the molecular recognition process have been determined using NMR techniques and molecular 
modelling. ${ }^{25}$ The different configuration at sulfur resulted in dissimilar conformational behavior and in a distinctive geometrical disposition of the molecule in the active site of the enzyme. These structural modifications justify the different rates of hydrolysis observed for each diastereoisomer.

Due to the importance of a specific configuration at the sulfur stereocenter of sulfoxides and as continuation of our previous work on this subject, we report herein the study of the oxidation of 3-deoxy-S-(1 $\rightarrow 4)$-disaccharides, with the aim of achieving high diastereoselectivity in the reaction.

\section{Results and discussion}

In order to determine the influence of the C- 6 substituent of the reducing end, vicinal to the sulfur at $\mathrm{C}-4$, on the stereochemical course of the oxidation of this atom, a series of 3-deoxy- $S$ - $(1 \rightarrow 4)$ disaccharides was synthesized. Thus, the synthetic route employed involved the conjugate addition of 1-thioaldose derivatives to sugar enones followed by reduction of the carbonyl group, which proved to be highly diastereoselective and high yielding. ${ }^{17,19}$ As Michael acceptors, the sugar enones 1-3, with the C-6 hydroxyl group unprotected (2) or substituted as acetyl ester (1) or tert-butyldimethylsilyl ether (TBS, 3), were prepared (Scheme 1). The enone 1 was obtained by the methodology previously described. ${ }^{26}$ The deacetylation of 1 to afford 2 was conducted under mild conditions using bis(tributyltin) oxide ${ }^{27}$ (TBTO) in order to avoid the elimination of the AcO group at C-6.

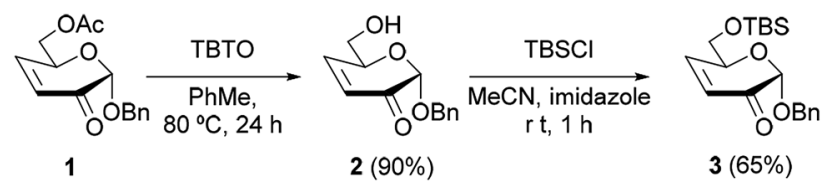

Scheme 1 Synthetic sequence to obtain $2 H$-pyran-3(6H)-ones $1-3$.
The silylation of the free hydroxyl group of 2 was performed with tert-butyldimethylsilyl chloride (TBSCl) in $\mathrm{MeCN}$ to give the enone 3.

The conjugate addition of 2,3,4,6-tetra- $O$-acetyl-1-thio- $\beta$-Dglucopyranose $^{28}(\mathbf{4})$ to $2 H$-pyran-3(6H)-ones 1 or 3 was conducted at $-18{ }^{\circ} \mathrm{C}$ for $1.5 \mathrm{~h}$, in the presence of a catalytic amount of triethylamine $\left(\mathrm{Et}_{3} \mathrm{~N}\right)$. As already described in previous work, and to avoid the retro-Michael reaction, ${ }^{19}$ the crude mixture of 2-keto thiodisaccharides 5 (Scheme 2) was treated with sodium borohydride in $\mathrm{MeOH}\left(0{ }^{\circ} \mathrm{C}, 30 \mathrm{~min}\right)$ for the reduction of the carbonyl group, to afford the 3-deoxy-4-S-glycosyl-4thiohexopyranosides 6-8 (from 1) and 9-11 (from 3). The control of the temperature was important in order to increase the diastereoselectivity during the sequence. The $\mathrm{NaBH}_{4}$ reduction requires also a short time, as longer reaction times led to partial de-O-acetylation of the products.

The mixtures obtained were subjected to column chromatography. The major product isolated starting from 1 was the thiodisaccharide 6 . The ${ }^{1} \mathrm{H}$ NMR spectrum of 6 revealed small coupling constant values for $4-\mathrm{H}$, which appeared as a broad singlet, and for $2-\mathrm{H}\left(J_{1,2}=3.5 \mathrm{~Hz}, J_{2,3 \mathrm{eq}}=J_{3 \mathrm{eq}, 4}=3.7 \mathrm{~Hz}\right)$ indicating the $R$ configuration for the new stereocenters at $\mathrm{C}-4$ and C-2 (3-deoxy-D-xylo-hexopyranoside configuration for the reducing end). Similarly, the coupling constant values determined for $4-\mathrm{H}\left(J_{3 \mathrm{ax}, 4}=J_{4,5}=12.8, J_{3 \text { eq. } 4}=3.9 \mathrm{~Hz}\right)$ and for $2-\mathrm{H}$ $\left(J_{1,2}=1.8, J_{2,3 \mathrm{eq}}=4.3, J_{2,3 \mathrm{ax}}=12.3 \mathrm{~Hz}\right)$, are indicative that the thiodisaccharide $\mathbf{8}$, which was isolated as a minor product, possessed respectively the $R$ and $S$ configuration at C-2 and C- 4 (3-deoxy-D-ribo-hexopyranoside). The large $J$ values observed for $J_{2,3 \mathrm{ax}}, J_{3 \mathrm{ax}, 4}$ and $J_{4,5}$ are result of the axial disposition for both $2-\mathrm{H}$ and $4-\mathrm{H}$, in the preferred chair conformation of the 3-deoxypyranoside unit. A third minor component of the mixture was the thiodisaccharide 7 , which was contaminated with a nonreduced 2-keto thiodisaccharide 5. However, some signals such as $1-\mathrm{H}$ (broad singlet), $2-\mathrm{H}\left(J_{2,3 \mathrm{a}}=J_{2,3 \mathrm{~b}}=4.6 \mathrm{~Hz}\right)$ and $4-\mathrm{H}$

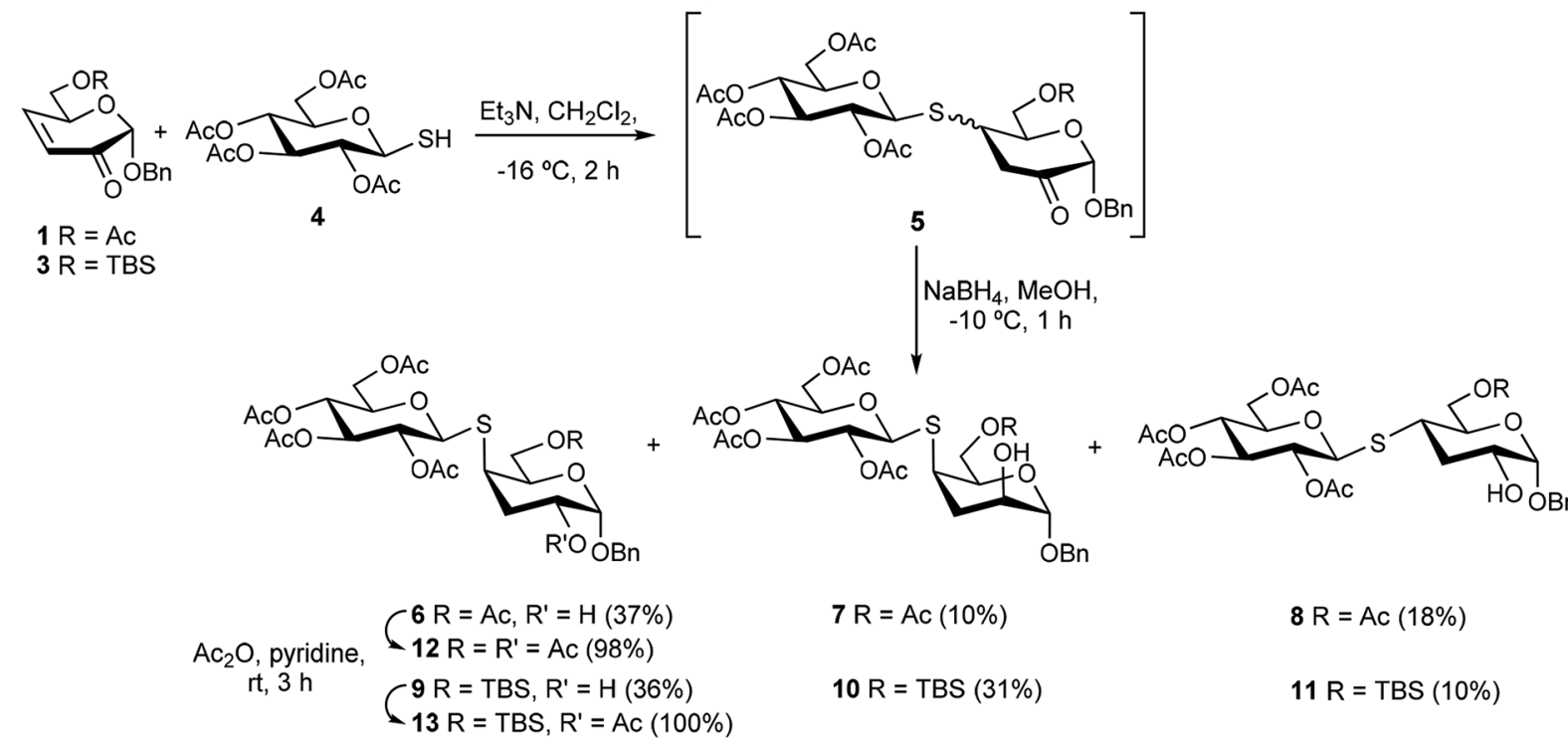

Scheme 2 Michael addition of thioaldose 4 to $2 H$-pyran-3(6H)-ones 1 and 3, followed by reduction, to afford thiodisaccharides $6-11$. 
(broad singlet) allowed us to assign the configuration of the reducing end of 7 as 3-deoxy-D-lyxo-hexopyranoside.

Thiodisaccharide 9 was the main product obtained from the enone 3. This compound showed the same configuration at C-4 and $\mathrm{C}-2$ as that of 6 , with equatorial disposition for $4-\mathrm{H}$ (broad doublet) and axial for $2-\mathrm{H}\left(J_{1,2}=3.7, J_{2,3 \mathrm{eq}}=3.3 \mathrm{~Hz}\right)$.

The thiodisaccharides $\mathbf{1 0}$ and $\mathbf{1 1}$ were also isolated as an inseparable mixture, in a $3.3: 1$ ratio, respectively. The configuration of the new stereocenters at C-4 and C-2 of $\mathbf{1 0}$ and $\mathbf{1 1}$ were also assigned on the basis of ${ }^{1} \mathrm{H}$ NMR signals that appeared in a clean region of the spectrum (no overlapped with other resonances). In the case of $\mathbf{1 0}$, the small coupling constant values for 4-H (broad doublet) and 1- $\mathrm{H}$ (broad singlet) suggested an equatorial disposition for both protons (3-deoxy-D-lyxohexopyranoside configuration). The NMR spectrum of thiodisaccharide 11 showed coupling constant values for $4-\mathrm{H}\left(J_{3 \mathrm{ax}, 4}\right.$ $\left.=13.5, J_{3 \mathrm{eq}, 4}=4.2, J_{4,5}=11.1 \mathrm{~Hz}\right)$ and $2-\mathrm{H}\left(J_{1,2}=3.5, J_{2,3 \mathrm{ax}}=\right.$ $12.4 \mathrm{~Hz}$ ) in agreement with the axial disposition of $4-\mathrm{H}$ and $2-\mathrm{H}$ (3-deoxy-D-ribo-hexopyranoside configuration).

The diastereofacial selectivity observed for the conjugate addition reaction was attributed to the stereocontrol exerted by the axial disposition of the benzyloxy group of dihydropyranones $\mathbf{1}$ and 3 , in the preferred ${ }^{0} \mathrm{H}_{5}$ conformation. ${ }^{29}$ This conformation is stabilized by the anomeric effect, increased by the carbonyl group vicinal to the anomeric position, ${ }^{30}$ and also because of the equatorial orientation of the bulky substituted hydroxymethyl group. Similarly, the diastereofacial selectivity in the borohydride reduction, in favor of the thiodisaccharides 6 and $\mathbf{8}$, was also attributed to the stereocontrol produced by the axial benzyloxy group, which induced the approach of the hydride from the Si face of the carbonyl. On the other hand, the reduction of the 6-O-TBS substituted intermediate 5 , led to an approximately $1: 1$ ratio of $9: 10$. Probably the steric hindrance generated by the silyloxymethyl group (even in an equatorial disposition) in combination with the axially disposed thioglycoside unit, both opposite to the benzyloxy group, could encumber the stereocontrol exerted by this anomeric substituent, leading to a higher proportion of 10.

The free hydroxyl group of thiodisaccharides 6 and 9 was subjected to acetylation leading to compounds 12 and 13, which differ in the substitution at C-6. Furthermore, in order to obtain an analogue with the 6-OH unprotected, the TBS group of compound 13 was removed using a solution of tetrabutylammonium fluoride (TBAF) in THF to afford the desired thiodisaccharide 14 (Scheme 3).

Having in hand the thiodisaccharides 12-14, with the same configuration of all the stereocenters but different substitution at 6-C (OAc, OTBS and $\mathrm{OH})$, they were subjected to oxidation of

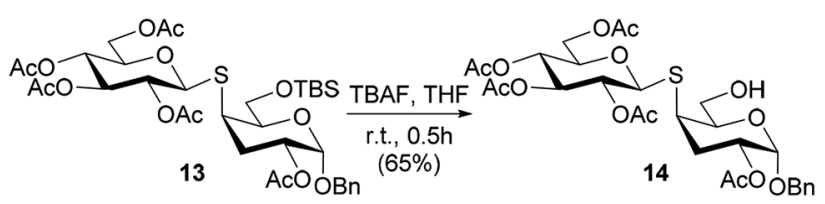

Scheme 3 Desilylation reaction of compound 13 to obtain the thiodisaccharide 14 the sulfur atom employing $m$-chloroperoxybenzoic acid $(m$ CPBA) (Scheme 4). The reaction was conducted in $1: 1 \mathrm{CH}_{2} \mathrm{Cl}_{2} /$ $\mathrm{Et}_{2} \mathrm{O}$ at $0{ }^{\circ} \mathrm{C}$ for $30 \mathrm{~min}$, in order to prevent the oxidation to the sulfone. Thus, the oxidation of $\mathbf{1 2}$ or $\mathbf{1 3}$ gave the diastereomeric mixture of sulfoxides $15 R, S$ or $16 R, S$, respectively. These poor selectivity is in agreement with the results of Crich and coworkers, ${ }^{31}$ who reported that oxidation of equatorial thioglicosides ( $\beta$ configuration) afforded mixtures of sulfoxides, while the oxidation of axial thioglycosides ( $\alpha$ configuration) are usually highly diastereoselective.

All the efforts to separate the diastereomeric mixture $15 R, S$ were unsuccessful. However, isomer $\mathbf{1 5 R}$ could be isolated in pure form by means of the procedure described below. Fortunately, the mixture of sulfoxides $16 R$ and $16 S$, obtained from 13 in $96 \%$ overall yield, could be separated by column chromatography. Interestingly, the oxidation of $\mathbf{1 4}$ was highly diastereoselective to afford 17 as a single product in $80 \%$ yield. The stereoisomer $\mathbf{1 5 R}$ was obtained through a short synthetic route starting from $16 R$, which was treated with TBAF for $O$-desilylation to afford $17 R$. The NMR spectra of $17 R$ were identical to the product of oxidation of 14 . Acetylation of $17 R$ led to $15 R$.

The absolute configuration at the sulfur stereocenter of each individual sulfoxide was determined following the procedure reported from our laboratory. ${ }^{\mathbf{2 0 , 2 1}}$ For this purpose, it was necessary to establish the predominant conformations adopted for each diastereoisomer, as result of the rotation of the thioglycosidic linkage. These conformations (rotamers) can be described according to the torsion angles $\phi\left(\mathrm{H}-1^{\prime}-\mathrm{C}-1^{\prime}-\mathrm{S}-\mathrm{C}-4\right)$ and $\psi\left(\mathrm{C}-\mathbf{1}^{\prime}-\mathrm{S}-\mathrm{C}-4-4-\mathrm{H}\right)$ defined for such a linkage. The presence of a given rotamer may be determined by the experimental detection of characteristic interresidue NOE interactions. ${ }^{\mathbf{1 6 , 3 2 - 3 4}}$ Furthermore, the shielding/deshielding effects on the signals of specific protons in the ${ }^{1} \mathrm{H}$ NMR spectrum were analyzed. Such effects are produced by the anisotropy of $\mathrm{S}=\mathrm{O}$ bond (considered to be of acetylenic character and with axial symmetry) and with the shielding cones oriented along the $\mathrm{S}=\mathrm{O}$ linkage. ${ }^{35}$ Additionally, the shielding effect on hydrogen atoms disposed $\alpha$ anti-axial to the lone pair of electrons of the sulfoxide group must be considered, as well as the deshielding of protons having a $s y n$-axial orientation with respect to the $\mathrm{S}=\mathrm{O}$ bond. ${ }^{35-38}$

The oxidation of $\mathbf{1 2}$ afforded an inseparable mixture of sulfoxides $15 R, S$ (which was later determined to be in a ratio 15R : $15 S$.4: 1). The ${ }^{1} \mathrm{H}$ and ${ }^{13} \mathrm{C}$ NMR spectra of the mixture were clear enough to assign all the signals of each individual sulfoxide. As explained above, the assignment of the sulfur atom configuration required the evaluation of the conformation of these molecules. The coupling constants values $(J)$ observed for the vicinal protons of $\mathbf{1 5}$ indicated, as expected, a strong preference for the ${ }^{4} \mathrm{C}_{1}$ conformation of both hexopyranose rings. These conformations were confirmed, for each diastereoisomer, by the presence of characteristic intraresidue NOE cross peaks $\left(3 \mathrm{ax}-\mathrm{H}-5-\mathrm{H} ; 1^{\prime}-\mathrm{H}-3^{\prime}-\mathrm{H}, 1^{\prime}-\mathrm{H}-5^{\prime}-\mathrm{H}, 3^{\prime}-\mathrm{H}-5^{\prime}-\mathrm{H}\right.$, and $2^{\prime}-$ $\mathrm{H}-4^{\prime}-\mathrm{H}$ ) in the NOESY spectrum of 15 . Key interresidue NOE contacts were also detected, that allowed the assignment of the most populated rotamers around of the thioglycosidic linkage. Thus, the major isomeric sulfoxide (later assigned as 15R) showed an intense interresidue NOE contact between $3 \mathrm{eq}-\mathrm{H}-\mathbf{1}^{\prime}$ - 


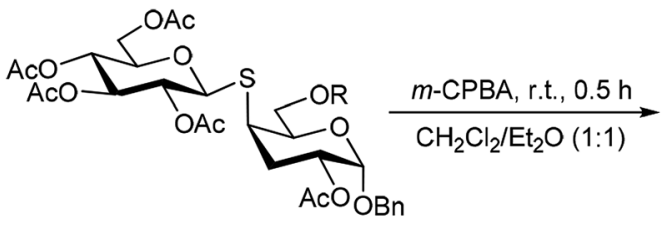

$12 \mathrm{R}=\mathrm{Ac}$

$13 \mathrm{R}=\mathrm{TBS}$

$14 \mathrm{R}=\mathrm{H}$

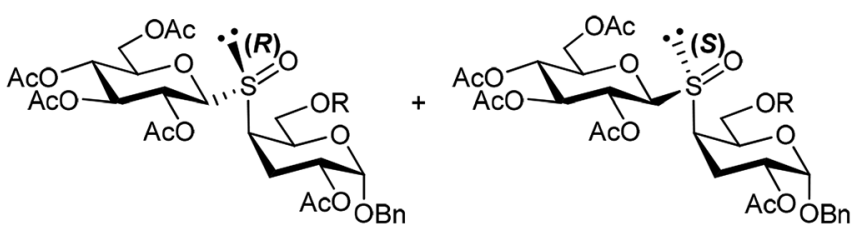

$15 R+15 S(74 \%$, ratio $R / S 1.4: 1), R=A c$

$16 R(59 \%), R=$ TBS

$17 R(80 \%), \mathrm{R}=\mathrm{H}$
$16 S(37 \%), R=$ TBS

$17 S(0 \%), R=H$

Scheme 4 Oxidation reaction of thiodisaccharides 12-14.

$\mathrm{H}$, and a barely perceptible cross-peak between $4-\mathrm{H}-\mathbf{1}^{\prime} \mathrm{H}$ suggesting the presence of the syn $\phi / \operatorname{syn} \psi$ rotamer. The lack of NOE interactions between $2-\mathrm{H}-1^{\prime}-\mathrm{H}$ and $4-\mathrm{H}-2^{\prime}-\mathrm{H}$ revealed that the respective syn $\phi / a n t i \psi$ and anti $\phi /$ syn $\psi$ rotamers were practically absent. This result is in agreement with the reported preferred conformation adopted for $(1 \rightarrow 4)$-thiodisaccharides. ${ }^{32,33}$ This rotamer is stabilized by the exo-anomeric effect generated by the sulfur lone-pair disposed anti to the polar $\mathrm{C}-1^{\prime}-\mathrm{O}-1^{\prime}$ bond. Similarly to $15 R$, the NOESY spectrum of $15 S$ showed as major rotamer the syn $\phi / \operatorname{syn} \psi$ (cross peak between $4-\mathrm{H}-1^{\prime}-\mathrm{H}$ ) and the anti $\phi /$ syn $\psi$ (weak cross peak $4-\mathrm{H}-2^{\prime}-\mathrm{H}$ ) as minor conformer.

On the other hand, the oxidation reaction of thiodisaccharide 13 afforded the sulfoxides $16 R$ ( $59 \%$ yield) and $\mathbf{1 6 S}$ (37\%), which were separated by column chromatography. The coupling constants values $(J)$ observed for the vicinal protons of $16 R$ and $16 S$ also indicated, the almost exclusive ${ }^{4} \mathrm{C}_{1}$ conformation of both hexopyranose rings. The presence of some characteristic intraresidue NOE cross peaks in the NOESY spectra of these sulfoxides also confirmed this observation $\left(1^{\prime}\right.$ $\mathrm{H}-3^{\prime}-\mathrm{H}, 1^{\prime}-\mathrm{H}-5^{\prime}-\mathrm{H}, 3^{\prime}-\mathrm{H}-5^{\prime}-\mathrm{H}$, and $\left.2^{\prime}-\mathrm{H}-4^{\prime}-\mathrm{H}\right)$. The predominance of the syn $\phi / \operatorname{syn} \psi$ form for $16 \boldsymbol{R}$ was established on the basis of the NOE interactions between $3 \mathrm{eq}-\mathrm{H}-\mathbf{1}^{\prime}-\mathrm{H}$. The detection of a very weak interaction $4-\mathrm{H}-2^{\prime}-\mathrm{H}$ suggested low population of the anti $\phi / s y n \psi$ conformer. Similarly, the isomer $16 S$ showed the same preference for the syn $\phi /$ syn $\psi$ rotamer (strong interaction between $4-\mathrm{H}-1^{\prime}-\mathrm{H}$ ) and the barely perceptible crosspeak $4 \mathrm{H}-2^{\prime}-\mathrm{H}$ was indicative of a very low population of the anti $\phi / s y n \psi$ form.

Interestingly, oxidation of the thiodisaccharide 14 was highly diastereoselective to give the sulfoxide $\mathbf{1 7} \boldsymbol{R}$ as the unique isomer, in $80 \%$ yield. As for the other sulfoxides already

Table 1 Relevant ${ }^{1} \mathrm{H}$ NMR chemical shift values of thiodisaccharide sulfoxides useful to determine the absolute configuration at sulfur stereocenter

\begin{tabular}{llllll}
\hline & \multicolumn{5}{l}{ Chemical shift $\delta[\mathrm{ppm}]$} \\
\cline { 2 - 6 } Sulfoxide & $2-\mathrm{H}$ & 3eq-H & $5-\mathrm{H}$ & $6 \mathrm{a}-\mathrm{H}$ & $6 \mathrm{~b}-\mathrm{H}$ \\
\hline $\mathbf{1 5 R}$ & 4.70 & 2.01 & 4.66 & 4.46 & 4.46 \\
$\mathbf{1 5 S}$ & 5.22 & 2.50 & 4.54 & 4.22 & 4.22 \\
$\mathbf{1 6 R}$ & 4.67 & 2.03 & 4.55 & 4.02 & 3.86 \\
$\mathbf{1 6 S}$ & 5.18 & 2.40 & 4.32 & 3.72 & 3.72 \\
$\mathbf{1 7 R}$ & 4.60 & 2.05 & 4.50 & 3.81 & 3.74
\end{tabular}

described, $\mathbf{1 7 R}$ showed a preference for the ${ }^{4} \mathrm{C}_{1}$ conformation for both hexopyranose rings, and the intense cross peak 3eq- $\mathrm{H}-$ $1^{\prime}-\mathrm{H}$ in the NOESY spectrum suggested the syn $\phi /$ syn $\psi$ as the main rotamer.

Finally, the absolute configuration of the sulfur stereocenter of each sulfoxide was established according to the chemical shifts observed in their respective ${ }^{1} \mathrm{H}$ NMR spectra. The chemical shift values for the signals of the more relevant protons are listed in Table 1. As can be seen, the protons 2- $\mathrm{H}$ and 3eq- $\mathrm{H}$ are more deshielded in $\mathbf{1 5 S}$ than in $15 R$, while $5-\mathrm{H}, 6 \mathrm{a}-\mathrm{H}$ and $6 \mathrm{~b}-\mathrm{H}$ are more shielded in $\mathbf{1 5 S}$ compared with $15 R$. These chemical shift differences could be explained considering the anisotropic effects of the $\mathrm{S}=\mathrm{O}$ bond on the given protons, according to their relative special orientation. Thus, as shown in Fig. 1, in the syn $\phi / s y n *$ conformation of $\mathbf{1 5 S}$ ( $S$ configuration at the sulfur stereocenter) the protons $2-\mathrm{H}$ and $3 \mathrm{eq}-\mathrm{H}$ are located within the deshielding cone of $\mathrm{S}=\mathrm{O}$ bond; while $5-\mathrm{H}, 6 \mathrm{a}-\mathrm{H}$ and $6 \mathrm{~b}-\mathrm{H}$ are placed near to the sulfur lone pair, lying in a shielding zone. Similar effects operating in the syn $\phi / s y n \psi$ conformation of isomer $15 R$ justify the chemical shifts observed. Thus, the signals of 2-H and 3eq-H appeared upfield in $15 R$, with respect to those of $\mathbf{1 5 S}$, as such protons are sited near to sulfur lone pair, in a protection zone. In contrast $5-\mathrm{H}, 6 \mathrm{a}-\mathrm{H}$ and $6 \mathrm{~b}-\mathrm{H}$ are located in the deshielding region of the $\mathrm{S}=\mathrm{O}$ bond.

The same analysis allowed us to establish the absolute configuration at the sulfur atom of $16 S$ and $16 R$. As these isomers are populating the same rotamer conformations as found for $16 S$ and $16 R$, respectively, the invoked anisotropic effects justify the chemical shifts of the protons located near to the $\mathrm{S}=\mathrm{O}$ group. Thus, the signal of $2-\mathrm{H}$ and 3 eq- $\mathrm{H}$ are shifted downfield in $16 S$ respect to $16 R$, while the opposite displacements are observed for the signals of $5-\mathrm{H}, 6 \mathrm{a}-\mathrm{H}$ and $6 \mathrm{~b}-\mathrm{H}$, which are shifted upfield in $\mathbf{1 6 S}$ respect to $16 R$. It is worth to mention that our assignments are in agreement with those predicted by the empirical rule which states that the signal of the anomeric carbon (C-1') of the $R_{\mathrm{S}}$ diastereoisomer is shielded upfield with respect to the same signal in the $S_{\mathrm{S}}$ counterpart. ${ }^{23,39}$

The absolute configuration of $\mathbf{1 7} \boldsymbol{R}$ was assigned, as a first approximation, by comparison of the chemical shift values of the signals of $2-\mathrm{H}$ and 3 eq- $\mathrm{H}$ of $\mathbf{1 7} \boldsymbol{R}$ with those of sulfoxides $15 S$, $15 R, 16 S$ and $16 R$. These two protons, in contrast with 5-H, 6a-H and $6 \mathrm{~b}-\mathrm{H}$, are located at a major distance of $\mathrm{C}-6$, and therefore are less affected by the electronic properties of different 


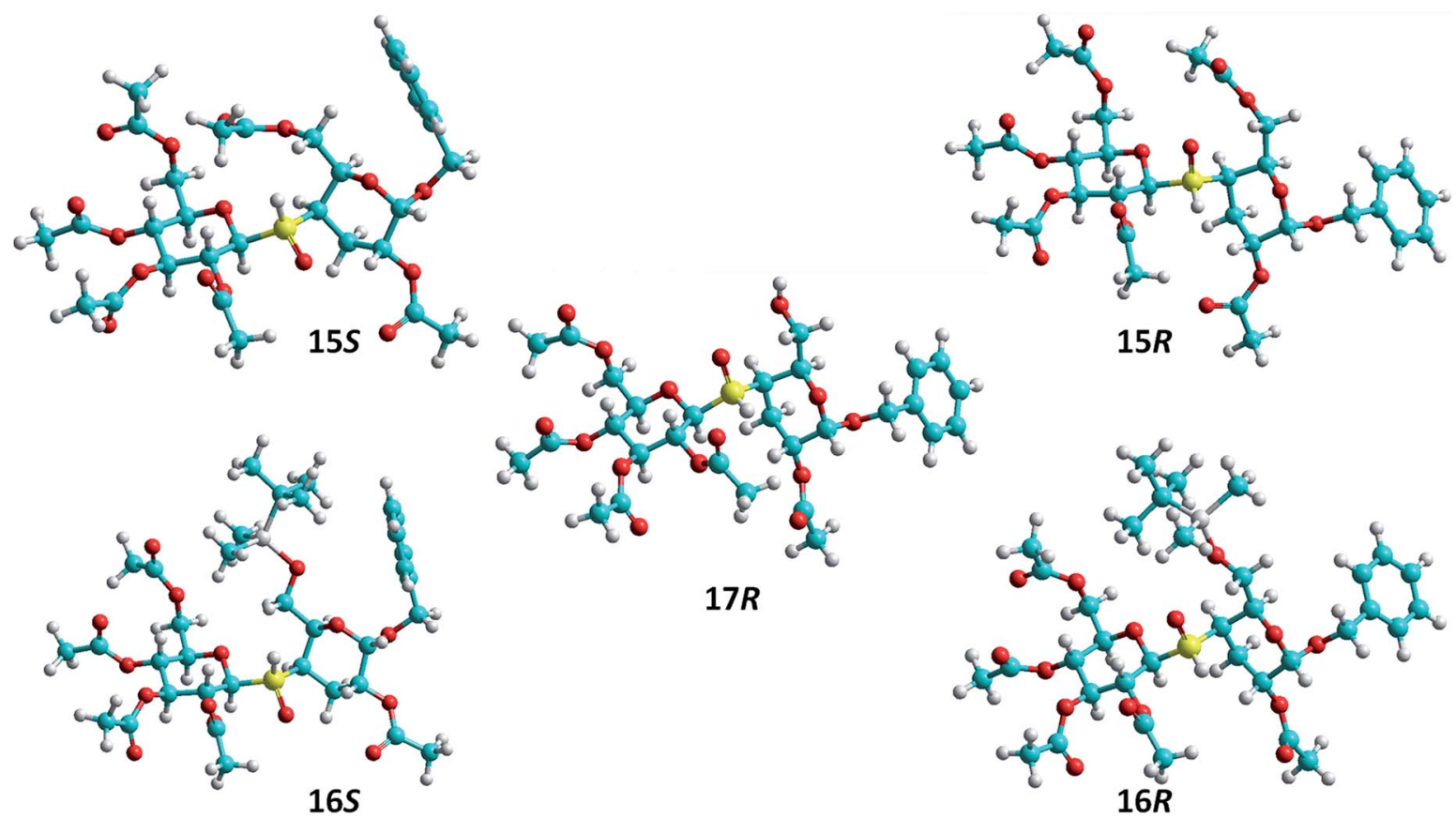

Fig. 1 Conformations of thiodisaccharide sulfoxides $15 S, 15 R, 16 S, 16 R$ and $17 R$ in the predominant conformation syn $\phi /$ syn $\psi$, based on the NOE interactions detected.

substituents at C-6. Thus, the chemical shift values observed for the signals of $2-\mathrm{H}$ and 3eq- $\mathrm{H}$ of $\mathbf{1 7 R}$ (Table 1 ), and also the $\delta_{1-\mathrm{C}^{\prime}}$, were very similar to those measured for $15 R$ and $16 R$, suggesting that the absolute configuration of the sulfoxide was also $R$. It is important to mention that this analysis could be performed, because all the thiodisaccharide sulfoxides present the same preferred syn $\phi /$ syn $\psi$ conformation. Therefore, the relative orientations and anisotropic effects of the $\mathrm{S}=\mathrm{O}$ bond are expected to be very similar for compounds with the same $\mathrm{S}=\mathrm{O}$ configuration. This assignment was confirmed by conducting the silylation of the OH- 6 of $\mathbf{1 7 R}$. The NMR spectra of the product obtained were identical to those of $15 R$, indicating that $17 R$ possessed the same absolute $R$ configuration at the sulfur stereocenter.

Next, in order to determine the diastereoselectivity observed in the oxidation reaction of $\mathbf{1 2 - 1 4}$, the conformations of these thiodisaccharides were assessed. As for the corresponding sulfoxides, the NOESY spectra of thiodisaccharides 12-14 exhibited clear $3 \mathrm{eq}-\mathrm{H}-1^{\prime}-\mathrm{H}$ and $4-\mathrm{H}-1^{\prime} \mathrm{H}$ interresidue cross peaks, suggesting again the syn $\phi / s y n \psi$ as major rotamer in the conformational equilibrium. The diastereoselectivity in the oxidation of thiodisaccharides $\mathbf{1 2}$ and $\mathbf{1 3}$ were similar, even when the size of the substituents of C-6, vicinal to the sulfur atom, is different (tert-butyldimethylsilyloxy versus acetoxy). In order to explain this behavior, the spatial arrangement of the TBSO group of $\mathbf{1 3}$ was investigated by NOESY spectroscopy. The NOESY spectrum of $\mathbf{1 3}$ showed NOE interactions between the methyl and $t$-butyl protons of TBS with $5-\mathrm{H}$ as well as between the TBS-t-butyl and $\mathrm{PhCH}_{2} \mathrm{O}$ protons. These cross peaks suggested that the TBS group was located remote to the sulfur reactive center (probably in a gt conformation for the substituted hydromethyl group) and hence the steric hindrance of TBS on sulfur should be negligible. Therefore, the chemical environment of sulfur should be similar in the preferred syn $\phi /$ syn $\psi$ conformation of thiodisaccharides $\mathbf{1 2}$ and $\mathbf{1 3}$, giving rise to a similar diastereoselectivity during the oxidation. On the other hand, the NOESY spectrum of $\mathbf{1 4}$ showed a NOE interaction between $\mathrm{OH}$ and $\mathrm{H}-4$, indicating that the hydroxyl group was disposed in the proximity of the sulfur reactive center. Therefore, as described for the epoxidation reaction of allylic alcohols (Henbest rule), ${ }^{\mathbf{4 0 , 4 1}}$ the hydroxyl group at C-6 can interact by hydrogen bonding with $m$-CPBA, and then deliver the oxidant to the pro- $(R)$ lone pair of electrons of $\mathrm{S}$, which is the closer electron pair in space in the syn $\phi / s y n \psi$ conformation, with complete diastereoselectivity (Scheme 5).

Once stablished the configuration at the sulfur stereocenter of all thiodisaccharides $S$-oxides, we proceed with the $O$-deacetylation of the sulfoxide obtained with complete diastereoselectivity $\mathbf{1 7 R}$. The hydrolysis of the acetyl protecting groups was performed with a mixture of $\mathrm{MeOH} / \mathrm{Et}_{3} \mathrm{~N} / \mathrm{H}_{2} \mathrm{O}(4: 1: 5)$ to

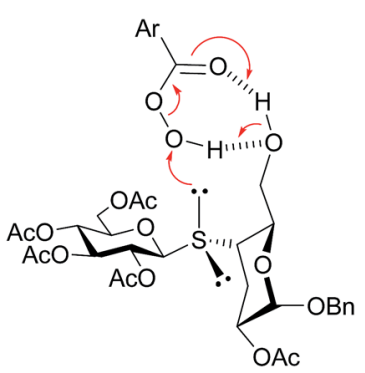

Scheme 5 Diastereoselective delivery of oxygen from $m$-CPBA to the pro- $(R)$ lone pair of electrons of sulfur of 14. 


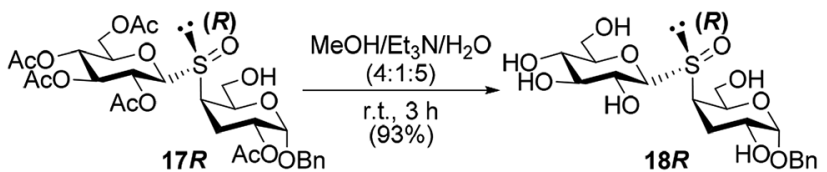

Scheme 6 Deprotection of thiodisaccharide S-oxide 17R.

lead the free 3 -deoxy-S- $(1 \rightarrow 4)$-disaccharide $S$-oxide $18 R$ in very good yield (Scheme 6). The evaluation of the free glycosyl sulfoxide as enzyme inhibitor, as well as antitumor agents, is underway.

\section{Conclusions}

The oxidation reaction of the sulfur atom of benzyl 2-O-acetyl-3deoxy-4-S-(2,3,4,6-tetra- $O$-acetyl- $\beta$-D-glucopyranosyl)-4-thio- $\beta$-Dxylo-hexopyranosides, with different substituents on C-6 (1214), was performed employing $m$-CPBA as oxidant. The absolute configuration at the sulfur stereocenter of each sulfoxide was established taking into account shielding/deshielding anisotropic effects of the $\mathrm{S}=\mathrm{O}$ bond on the chemical shift of the NMR signals of selected protons, in the most populated syn $\phi / s y n \psi$ conformation of the thiodisaccharide $S$-oxides.

Oxidation of the sulfur atom of thiodisaccharides with the hydroxymethyl group (C-6) substituted with acetyl (12) or TBS (13) afforded the diastereomeric mixtures of sulfoxides $15 R, S$ and $16 R, S$, in a similar ratio (1.4:1 and $1.6: 1$, respectively). In contrast, the oxidation of thiodisaccharide 14, with a free hydroxyl group at C-6 led to a single sulfoxide with $R$ configuration $(\mathbf{1 7 R})$. Under the reaction conditions employed, the oxidation of all the thiodisaccharides studied was in favor of the $R$-isomer. The selectivity observed may be justified taking into account that, in the most populated syn $\phi / \operatorname{syn} \psi$ conformer of the precursors, the pro- $(R)$ lone pair of electrons of sulfur is less hindered that the pro- $(S)$. The comparable selectivity in the oxidation reaction of $\mathbf{1 2}$ and $\mathbf{1 3}$ suggested a similar environment around the sulfur atom. In fact, the TBS substituent on $\mathbf{1 3}$ was located remote to this reactive center (as shown by NOE experiments) and the steric hindrance produced by the bulky group should be negligible. The asymmetric induction in the oxidation of $\mathbf{1 4}$ may be attributed to a hydrogen bonding interaction of the $\mathrm{OH}$ group with $m$-CPBA, delivering the oxidant to the pro- $(R)$ lone pair of electrons, which is closer in space in the syn $\phi / \operatorname{syn} \psi$ conformation of the thiodisaccharide. In agreement with this result, an enhanced diastereoselectivity was observed for the oxidation of thioglycosides when the vicinal $\mathrm{OH}$ group at $\mathrm{C}-2$ was unprotected..$^{12,39}$

\section{Experimental section}

\section{General methods}

Column chromatography was carried out with silica gel $60(230-$ 400 mesh). Analytical thin-layer chromatography (TLC) was carried out on silica gel 60 F254 aluminium backed plates (layer thickness $0.2 \mathrm{~mm}$ ). Compounds were visualized by UV absorption at $254 \mathrm{~nm}$, and by charring with a solution of
$\left(\mathrm{NH}_{4}\right)_{6} \mathrm{Mo}_{7} \mathrm{O}_{24} \cdot 4 \mathrm{H}_{2} \mathrm{O} 25 \mathrm{~g} \mathrm{~L}^{-1},\left(\mathrm{NH}_{4}\right)_{4} \mathrm{Ce}\left(\mathrm{SO}_{4}\right)_{4} \cdot 2 \mathrm{H}_{2} \mathrm{O} 10 \mathrm{~g} \mathrm{~L}^{-1}$ and $10 \% \mathrm{H}_{2} \mathrm{SO}_{4}$ in $\mathrm{H}_{2} \mathrm{O}$. Optical rotations were measured at $25{ }^{\circ} \mathrm{C}$ in a $1 \mathrm{dm}$ cell in the solvent indicated. Nuclear magnetic resonance (NMR) spectra were recorded at 400 or $500 \mathrm{MHz}\left({ }^{1} \mathrm{H}\right)$ and 100.0 or 125.7 $\mathrm{MHz}\left({ }^{13} \mathrm{C}\right)$. Chemical shifts were referred to tetramethylsilane or to the residual solvent peak $\left(\mathrm{CHCl}_{3}:{ }^{1} \mathrm{H}: \delta=7.26 \mathrm{ppm},{ }^{13} \mathrm{C}\right.$ : $\delta=77.2 \mathrm{ppm})$. Assignments of ${ }^{1} \mathrm{H}$ and ${ }^{13} \mathrm{C}$ NMR spectra were supported by $2 \mathrm{D}{ }^{1} \mathrm{H}-\mathrm{COSY}$, NOESY and $2 \mathrm{D}^{1} \mathrm{H}^{1}{ }^{13} \mathrm{C}$ HSQC and HMBC experiments. High-resolution mass spectra (HRMS) were obtained using the electrospray ionization (ESI) technique and QTOF detection.

Benzyl 3,4-dideoxy- $\alpha$-D-glycero-hex-3-enopyranosid-2-ulose (2). A solution of enone $1(282 \mathrm{mg}, 1.01 \mathrm{mmol})$, TBTO $(1 \mathrm{~mL}, 1.96$ $\mathrm{mmol})$ in toluene $(8 \mathrm{~mL})$ was stirred at $80^{\circ} \mathrm{C}$ for $20 \mathrm{~h}$. The reaction was monitored by TLC (pentane/EtOAc, $1: 1$ ), until complete conversion of the starting material $\left(R_{\mathrm{f}}=0.80\right)$ into a more polar product $\left(R_{\mathrm{f}}=0.52\right)$. The mixture was concentrated and the residue dissolved in $\mathrm{MeCN}(60 \mathrm{~mL})$ and extracted with hexane $(4$ $\times 30 \mathrm{~mL}$ ). The acetonitrile phase was concentrated and the residue was purified by column chromatography using hexane/ EtOAc $(2: 1 \rightarrow 1: 1)$ as eluent, to give enone $2(213 \mathrm{mg}, 90 \%)$ as a light yellow syrup. $[\alpha]_{\mathrm{D}}^{28}=+65.5\left(c=1.0, \mathrm{CHCl}_{3}\right) .{ }^{1} \mathrm{H}$ NMR $(400$ $\left.\mathrm{MHz}, \mathrm{CDCl}_{3}\right): \delta=7.37-7.30\left(\mathrm{~m}, 5 \mathrm{H}, \mathrm{PhCH}_{2} \mathrm{O}\right), 6.98\left(\mathrm{dd}, J_{3,4}=10.6\right.$, $\left.J_{4,5}=1.6 \mathrm{~Hz}, 1 \mathrm{H}, 4-\mathrm{H}\right), 6.20\left(\mathrm{dd}, J_{3,4}=10.6, J_{3,5}=2.3 \mathrm{~Hz}, 1 \mathrm{H}, 3-\mathrm{H}\right)$, $5.00(\mathrm{~s}, 1 \mathrm{H}, 1-\mathrm{H}), 4.83\left(\mathrm{~d}, J=11.8 \mathrm{~Hz}, 1 \mathrm{H}, \mathrm{PhCH}_{2} \mathrm{O}\right), 4.74(\mathrm{~d}, J=$ $\left.11.8 \mathrm{~Hz}, 1 \mathrm{H}, \mathrm{PhCH}_{2} \mathrm{O}\right), 4.61(\mathrm{~m}, 1 \mathrm{H}, 5-\mathrm{H}), 3.85$ (br. d, $J_{6 \mathrm{a}, 6 \mathrm{~b}}=$ $11.3 \mathrm{~Hz}, 1 \mathrm{H}, 6 \mathrm{a}-\mathrm{H}), 3.77\left(\mathrm{dd}, J_{6 \mathrm{a}, 6 \mathrm{~b}}=10.9, J_{5,6 \mathrm{~b}}=4.4 \mathrm{~Hz}, 1 \mathrm{H}, 6 \mathrm{~b}-\mathrm{H}\right)$, 1.90 (br. s, $1 \mathrm{H}, \mathrm{OH}) \mathrm{ppm} .{ }^{13} \mathrm{C}$ NMR $\left(100 \mathrm{MHz}, \mathrm{CDCl}_{3}\right): \delta=188.6$ (C-2), 148.2 (C-4), 136.8, 128.7, 128.3 (×2) (C-aromatic), 126.6 (C3), 97.3 (C-1), $71.3\left(\mathrm{PhCH}_{2} \mathrm{O}\right), 69.7$ (C-5), 64.4 (C-6) ppm. HRMS (ESI): calcd for $\mathrm{C}_{13} \mathrm{H}_{14} \mathrm{NaO}_{4} 257.0784[\mathrm{M}+\mathrm{Na}]^{+}$; found 257.0793.

Benzyl 3,4-dideoxy-6-O-(tert-butyldimethylsilyl)- $\alpha$-D-glycerohex-3-enopyranosid-2-ulose (3). To a solution of enone 2 (614 mg, $2.62 \mathrm{mmol}$ ) and TBSCl (526 mg, $3.49 \mathrm{mmol})$ in MeCN $(3.2 \mathrm{~mL})$ was added imidazole $(396 \mathrm{mg}, 5.82 \mathrm{mmol})$. The mixture was stirred at room temperature for $30 \mathrm{~min}$, when TLC (hexane/ EtOAc $1: 1)$ showed until complete conversion of the starting material $\left(R_{\mathrm{f}}=0.28\right)$ into a faster moving compound $\left(R_{\mathrm{f}}=0.82\right)$. The reaction mixture was diluted with $\mathrm{CH}_{2} \mathrm{Cl}_{2}(50 \mathrm{~mL})$ and washed with water $(3 \times 40 \mathrm{~mL})$. The organic layer was dried $\left(\mathrm{MgSO}_{4}\right)$ and filtered. The evaporation of the solvent gave an oily residue, which was purified by column chromatography employing hexane/EtOAc $(97: 3 \rightarrow 90: 10)$. The enone 3 was isolated as a syrup $(592 \mathrm{mg}, 65 \%) .[\alpha]_{\mathrm{D}}^{28}=+11.5\left(c=1.0, \mathrm{CHCl}_{3}\right)$. ${ }^{1} \mathrm{H}$ NMR $\left(500 \mathrm{MHz}, \mathrm{CDCl}_{3}\right): \delta=7.37-7.30\left(\mathrm{~m}, 5 \mathrm{H}, \mathrm{PhCH}_{2} \mathrm{O}\right), 7.11$ $\left(\mathrm{dd}, J_{3,4}=10.6, J_{4,5}=1.6 \mathrm{~Hz}, 1 \mathrm{H}, 4-\mathrm{H}\right), 6.16\left(\mathrm{dd}, J_{3,4}=10.6, J_{3,5}=\right.$ $2.4 \mathrm{~Hz}, 1 \mathrm{H}, 3-\mathrm{H}), 4.95(\mathrm{~s}, 1 \mathrm{H}, 1-\mathrm{H}), 4.83(\mathrm{~d}, J=11.7,1 \mathrm{H}$, $\left.\mathrm{PhCH}_{2} \mathrm{O}\right), 4.72\left(\mathrm{~d}, J=11.7,1 \mathrm{H}, \mathrm{PhCH}_{2} \mathrm{O}\right), 4.53(\mathrm{~m}, 1 \mathrm{H}, 5-\mathrm{H}), 3.86$ $\left(\mathrm{dd}, J_{6 \mathrm{a}, 6 \mathrm{~b}}=10.2, J_{5,6 \mathrm{a}}=5.6 \mathrm{~Hz}, 1 \mathrm{H}, 6 \mathrm{a}-\mathrm{H}\right), 3.67\left(\mathrm{dd}, J_{6 \mathrm{a}, 6 \mathrm{~b}}=10.0\right.$, $\left.J_{5,6 \mathrm{~b}}=7.0 \mathrm{~Hz}, 1 \mathrm{H}, 6 \mathrm{~b}-\mathrm{H}\right), 0.91\left(\mathrm{~s}, 9 \mathrm{H}, \mathrm{Si}\left(\mathrm{CH}_{3}\right)_{2} \mathrm{C}\left(\mathrm{CH}_{3}\right)_{3}\right), 0.10$, $0.09\left(2 \mathrm{~s}, 6 \mathrm{H}, \mathrm{Si}\left(\mathrm{CH}_{3}\right)_{2} \mathrm{C}\left(\mathrm{CH}_{3}\right)_{3}\right)$ ppm. ${ }^{13} \mathrm{C}$ NMR $(125.7 \mathrm{MHz}$, $\left.\mathrm{CDCl}_{3}\right): \delta=189.0(\mathrm{C}-2), 149.5(\mathrm{C}-4), 136.9,128.6,128.2(\times 2)(\mathrm{C}-$ aromatic), $125.4(\mathrm{C}-3), 97.1(\mathrm{C}-1), 71.0\left(\mathrm{OCH}_{2} \mathrm{Ph}\right), 69.6$ (C-5), 64.6 (C-6), $25.9\left(\mathrm{Si}\left(\mathrm{CH}_{3}\right)_{2} \mathrm{C}\left(\mathrm{CH}_{3}\right)_{3}\right), 18.4\left(\mathrm{Si}\left(\mathrm{CH}_{3}\right)_{2} \mathrm{C}\left(\mathrm{CH}_{3}\right)_{3}\right),-5.2(\times 2)$ $\left.\left(\mathrm{Si}\left(\mathrm{CH}_{3}\right)_{2} \mathrm{C}\left(\mathrm{CH}_{3}\right)_{3}\right)\right)$ ppm. HRMS (ESI): calcd for $\mathrm{C}_{19} \mathrm{H}_{28} \mathrm{NaO}_{4} \mathrm{Si}$ $371.1649[\mathrm{M}+\mathrm{Na}]^{+}$; found 371.1663. 
General procedure for the conjugate addition and $\mathrm{NaBH}_{4}$ reduction reactions

The corresponding $2 H$-pyran-3(6H)-one $(0.50 \mathrm{mmol})$ and thioaldose 4 (182 $\mathrm{mg}, 0.50 \mathrm{mmol})$ were dissolved in anhydrous $\mathrm{CH}_{2} \mathrm{Cl}_{2}(1.0 \mathrm{~mL})$ and cooled to $-18{ }^{\circ} \mathrm{C}$. A solution of $\mathrm{NEt}_{3}(3.8$ $\mu \mathrm{L})$ in $\mathrm{CH}_{2} \mathrm{Cl}_{2}(0.2 \mathrm{~mL})$ was added, and the mixture was stirred at $-18{ }^{\circ} \mathrm{C}$ for $1.5 \mathrm{~h}$, when TLC showed complete consumption of the starting materials. The mixture was concentrated and the residue was dissolved in dry $\mathrm{MeOH}(2.7 \mathrm{~mL})$ and treated with sodium borohydride $\left(21 \mathrm{mg}, 0.56 \mathrm{mmol}\right.$ ) at $0{ }^{\circ} \mathrm{C}$ for $30 \mathrm{~min}$. Then, the mixture was stirred in batch with Dowex 50W $(\mathrm{H}+)$ resin, filtered, and concentrated. Column chromatography of the residue with pentane/EtOAc $(4: 1 \rightarrow 1: 1)$ afforded the desired thiodisaccharides.

\section{Michael addition of thioaldose 4 to enone 1}

Benzyl 6-O-acetyl-3-deoxy-4- $S$-(2,3,4,6-tetra-O-acetyl- $\beta$-D-glucopyranosyl)-4-thio- $\alpha$-D-erythro-hexopyranosid-2-ulose (5) and benzyl 6-O-acetyl-3-deoxy-4- $S$-(2,3,4,6-tetra- $O$-acetyl- $\beta$-D-glucopyranosyl)-4-thio- $\alpha$-D-lyxo-hexopyranoside (7). Column chromatography of the residue afforded first the less polar products $\left(R_{\mathrm{f}}=\right.$ 0.34 , pentane/EtOAc, $1: 1$ ) which were identified as a mixture of non-reduced 2-keto thiodisaccharide 5 and thiodisaccharide 7 (56 mg, 17\%, ratio $5: 7,0.7: 1$ ), ${ }^{1} \mathrm{H} \mathrm{NMR}\left(400 \mathrm{MHz}, \mathrm{CDCl}_{3}\right.$ ) data for 5: $\delta=7.37-7.30\left(\mathrm{~m}, 5 \mathrm{H}, \mathrm{PhCH}_{2} \mathrm{O}\right.$ overlapping with $\mathrm{PhCH}_{2} \mathrm{O}$ of 7), $5.19\left(\mathrm{t}, J_{2^{\prime}, 3^{\prime}}=J_{3^{\prime}, 4^{\prime}}=9.3 \mathrm{~Hz}, 1 \mathrm{H}, 3^{\prime}-\mathrm{H}\right), 5.03\left(\mathrm{t}, J_{3^{\prime}, 4^{\prime}}=J_{4^{\prime}, 5^{\prime}}=\right.$ $\left.9.7 \mathrm{~Hz}, 1 \mathrm{H}, 4^{\prime}-\mathrm{H}\right), 4.95\left(\mathrm{dd}, J_{1^{\prime}, 2^{\prime}}=10.0, J_{2^{\prime}, 3^{\prime}}=9.4 \mathrm{~Hz}, 2^{\prime}-\mathrm{H}\right), 4.78(\mathrm{~s}$, $1 \mathrm{H}, 1-\mathrm{H}), 4.77\left(\mathrm{~d}, J=11.7 \mathrm{~Hz}, 1 \mathrm{H}, \mathrm{PhCH}_{2} \mathrm{O}\right), 4.62(\mathrm{~d}, J=12.5 \mathrm{~Hz}$, $\left.1 \mathrm{H}, \mathrm{PhCH}_{2} \mathrm{O}\right), 4.61\left(\mathrm{~d}, J_{1^{\prime}, 2^{\prime}}=9.9 \mathrm{~Hz}, 1 \mathrm{H}, 1^{\prime}-\mathrm{H}\right), 4.52\left(\mathrm{dd}, J_{6 \mathrm{a}, 6 \mathrm{~b}}=\right.$ $\left.11.7, J_{5,6 \mathrm{a}}=1.4 \mathrm{~Hz}, 1 \mathrm{H}, 6 \mathrm{a}-\mathrm{H}\right), 4.34\left(\mathrm{dd}, J_{6 \mathrm{a}, 6 \mathrm{~b}}=12.0, J_{5,6 \mathrm{~b}}=5.3 \mathrm{~Hz}\right.$, $1 \mathrm{H}, 6 \mathrm{~b}-\mathrm{H}), 4.29-4.19\left(\mathrm{~m}, 1 \mathrm{H}, 5-\mathrm{H}\right.$ overlapping with $6 \mathrm{a}-\mathrm{H}, 6 \mathrm{~b}-\mathrm{H}, 6^{\prime} \mathrm{a}-$ $\mathrm{H}$ of 7), 4.14 (m, 2H, 6' a-H, 6 $6^{\prime} \mathrm{b}-\mathrm{H}$ overlapping with $6^{\prime} \mathrm{b}-\mathrm{H}$ of 7$), 3.63$ $\left(\mathrm{ddd}, J_{4^{\prime}, 5^{\prime}}=9.9, J=5.2, J=2.3 \mathrm{~Hz}, 1 \mathrm{H}, 5^{\prime}-\mathrm{H}\right), 3.32(\mathrm{~m}, 1 \mathrm{H}, 4-\mathrm{H}$ overlapping with $4-\mathrm{H}$ of 7$), 2.91\left(\mathrm{dd}, J_{3 \mathrm{a}, 3 \mathrm{~b}}=15.0, J_{2,3 \mathrm{a}}=12.0 \mathrm{~Hz}\right.$, $1 \mathrm{H}, 3 \mathrm{a}-\mathrm{H}), 2.85\left(\mathrm{dd}, J_{3 \mathrm{a}, 3 \mathrm{~b}}=15.0, J_{2,3 \mathrm{~b}}=6.4 \mathrm{~Hz}, 1 \mathrm{H}, 3 \mathrm{~b}-\mathrm{H}\right), 2.11-$ $1.99\left(5 \mathrm{~s}, 15 \mathrm{H}, \mathrm{COCH}_{3}\right.$ overlapping with $\mathrm{COCH}_{3}$ of 7) ppm. ${ }^{13} \mathrm{C}$ NMR $\left(\mathrm{CDCl}_{3}, 100.0 \mathrm{MHz}\right)$ data for 5: $\delta=198.8(\mathrm{C}-2), 170.7-169.4$ $\left(\mathrm{COCH}_{3} \times 5\right.$ overlapping with $\mathrm{COCH}_{3}$ of 7$), 136.3,128.8,128.3$, 128.1 (C-aromatic), 98.2 (C-1), $83.0\left(\mathrm{C}-1^{\prime}\right), 76.0\left(\mathrm{C}-5^{\prime}\right), 73.7\left(\mathrm{C}-3^{\prime}\right)$, 70.3 (C-5), $70.2\left(\mathrm{C}-2^{\prime}\right), 70.1\left(\mathrm{PhCH}_{2} \mathrm{O}\right), 68.2\left(\mathrm{C}-4^{\prime}\right), 63.7$ (C-6), 62.1 (C-6'), 43.4 (C-3), 42.6 (C-4), 20.9-20.7 $\left(\mathrm{COCH}_{3} \times 5\right.$ overlapping with $\mathrm{COCH}_{3}$ of 7) ppm. HRMS (ESI) data for 5: calcd for $\mathrm{C}_{29} \mathrm{H}_{36} \mathrm{NaO}_{14} \mathrm{~S}$ 663.1718 [M + Na] $]^{+}$; found 663.1720. ${ }^{1} \mathrm{H}$ NMR (400 $\left.\mathrm{MHz}, \mathrm{CDCl}_{3}\right)$ data for disaccharide 7: $\delta=7.37-7.30(\mathrm{~m}, 5 \mathrm{H}$, $\mathrm{PhCH}_{2} \mathrm{O}$ overlapping with $\mathrm{PhCH}_{2} \mathrm{O}$ of 5), $5.23\left(\mathrm{t}, J_{2^{\prime}, 3^{\prime}}=J_{3^{\prime}, 4^{\prime}}=\right.$ $\left.9.3 \mathrm{~Hz}, 1 \mathrm{H}, 3^{\prime}-\mathrm{H}\right), 5.09\left(\mathrm{t}, J_{3^{\prime}, 4^{\prime}}=J_{4^{\prime}, 5^{\prime}}=9.1 \mathrm{~Hz}, 1 \mathrm{H}, 4^{\prime}-\mathrm{H}\right), 5.04(\mathrm{t}$, $\left.J_{1^{\prime}, 2^{\prime}}=J_{2^{\prime}, 3^{\prime}}=9.1 \mathrm{~Hz}, 1 \mathrm{H}, 2^{\prime}-\mathrm{H}\right), 4.85$ (br. s, $\left.1 \mathrm{H}, 1-\mathrm{H}\right), 4.73$ (d, $J=$ $\left.11.6 \mathrm{~Hz}, 1 \mathrm{H}, \mathrm{PhCH}_{2} \mathrm{O}\right), 4.67$ (d, $\left.J_{1^{\prime}, 2^{\prime}}=10.1 \mathrm{~Hz}, 1 \mathrm{H}, 1^{\prime}-\mathrm{H}\right), 4.50(\mathrm{~d}, J$ $\left.=11.6 \mathrm{~Hz}, 1 \mathrm{H}, \mathrm{PhCH}_{2} \mathrm{O}\right), 4.42(\mathrm{~m}, 1 \mathrm{H}, 5-\mathrm{H}), 4.29-4.19(\mathrm{~m}, 3 \mathrm{H}, 6 \mathrm{a}-$ $\mathrm{H}, 6 \mathrm{~b}-\mathrm{H}, 6^{\prime} \mathrm{a}-\mathrm{H}$, overlapping with $5-\mathrm{H}$ of 5 ), 4.10 (m, $1 \mathrm{H}, 6^{\prime} \mathrm{b}-\mathrm{H}$ overlapping with $6^{\prime} \mathrm{a}-\mathrm{H}$ and $6^{\prime} \mathrm{b}-\mathrm{H}$ of 5$), 3.70\left(\mathrm{~m}, 2 \mathrm{H}, 2-\mathrm{H}, 5^{\prime}-\mathrm{H}\right)$, 3.50 (d, $\left.J_{\mathrm{OH}, 2}=9.9 \mathrm{~Hz}, 1 \mathrm{H}, \mathrm{OH}\right) 3.32$ (br. s, $1 \mathrm{H}, 4-\mathrm{H}$ overlapping with $4-\mathrm{H}$ of 5$), 2.29(\mathrm{~m}, 2 \mathrm{H}, 3 \mathrm{a}-\mathrm{H}, 3 \mathrm{~b}-\mathrm{H}), 2.11-1.99(5 \mathrm{~s}, 15 \mathrm{H}$, $\mathrm{COCH}_{3}$ overlapping with $\mathrm{COCH}_{3}$ of 5) ppm. ${ }^{13} \mathrm{C} \mathrm{NMR}\left(\mathrm{CDCl}_{3}\right.$, 100.0 MHz) data for disaccharide 7: $\delta=170.7-169.4\left(\mathrm{COCH}_{3} \times 5\right.$ overlapping with $\mathrm{COCH}_{3}$ of 5), 137.1, 128.7, 128.5, 128.3 (C- aromatic), 99.9 (C-1), 82.2 (C-1'), 76.3 (C-5'), 73.9 (C-3'), 69.9 (C$\left.2^{\prime}\right), 69.2\left(\mathrm{PhCH}_{2} \mathrm{O}\right), 68.5$ (C-5), $68.2\left(\mathrm{C}-4^{\prime}\right), 67.1$ (C-2), 65.3 (C-6), 62.0 (C-6'), 39.1 (C-4), 30.9 (C-3), 20.9-20.7 $\left(\mathrm{COCH}_{3} \times 5\right.$ overlapping with $\mathrm{COCH}_{3}$ of 7) ppm. HRMS (ESI) data for 7: calcd for $\mathrm{C}_{29} \mathrm{H}_{38} \mathrm{NaO}_{14} \mathrm{~S} 665.1874[\mathrm{M}+\mathrm{Na}]^{+}$; found 665.1867.

Benzyl 6- $O$-acetyl-3-deoxy-4-S-(2,3,4,6-tetra- $O$-acetyl- $\beta$-D-glucopyranosyl)-4-thio- $\alpha$-D-xylo-hexopyranoside (6). Column chromatography of the residue afforded a second product $\left(R_{\mathrm{f}}=0.23\right.$, pentane/EtOAc, $1: 1$ ), which was identified as thiodisaccharide 6 (135 mg, 37\%). ${ }^{1} \mathrm{H}$ NMR (400 MHz, $\mathrm{CDCl}_{3}$ ): $\delta=7.38-7.30(\mathrm{~m}, 5 \mathrm{H}$, $\left.\mathrm{PhCH}_{2} \mathrm{O}\right), 5.20\left(\mathrm{t}, J_{2^{\prime}, 3^{\prime}}=J_{3^{\prime}, 4^{\prime}}=9.3 \mathrm{~Hz}, 1 \mathrm{H}, 3^{\prime}-\mathrm{H}\right), 5.07\left(\mathrm{t}, J_{3^{\prime}, 4^{\prime}}=J_{4^{\prime}, 5^{\prime}}\right.$ $\left.=9.7 \mathrm{~Hz}, 1 \mathrm{H}, 4^{\prime}-\mathrm{H}\right), 5.00\left(\mathrm{t}, J_{1^{\prime}, 2^{\prime}}=J_{2^{\prime}, 3^{\prime}}=9.6 \mathrm{~Hz}, 1 \mathrm{H}, 2^{\prime}-\mathrm{H}\right), 4.91(\mathrm{~d}$, $\left.J_{1,2}=3.5 \mathrm{~Hz}, 1 \mathrm{H}, 1-\mathrm{H}\right), 4.76\left(\mathrm{~d}, J=11.5 \mathrm{~Hz}, 1 \mathrm{H}, \mathrm{PhCH}_{2} \mathrm{O}\right), 4.58$ (d, $\left.J_{1^{\prime}, 2^{\prime}}=10.1 \mathrm{~Hz}, 1 \mathrm{H}, 1^{\prime}-\mathrm{H}\right), 4.51\left(\mathrm{~d}, J=11.5 \mathrm{~Hz}, 1 \mathrm{H}, \mathrm{PhCH}_{2} \mathrm{O}\right), 4.27$ (m, 1H, $5 \mathrm{H}), 4.23-4.11$ (m, 4H, 6a-H, 6b-H, 6' a-H, 6' b-H), 4.06 (m, $1 \mathrm{H}, 2-\mathrm{H}), 3.66\left(\mathrm{ddd}, J_{4^{\prime}, 5^{\prime}}=9.9, J_{5^{\prime}, 6^{\prime} \mathrm{a}}=4.6, J_{5^{\prime}, 6^{\prime} \mathrm{b}}=2.4 \mathrm{~Hz}, 1 \mathrm{H}, 5^{\prime}-\right.$ $\mathrm{H}), 3.32$ (br. s, $1 \mathrm{H}, 4-\mathrm{H}), 2.19\left(\mathrm{dt}, J_{3 \mathrm{a}, 3 \mathrm{~b}}=12.6, J_{2,3 \mathrm{a}}=J_{3 \mathrm{a}, 4}=3.7 \mathrm{~Hz}\right.$, $1 \mathrm{H}, 3 \mathrm{a}-\mathrm{H}), 2.09(\mathrm{~m}, 1 \mathrm{H}, 3 \mathrm{~b}-\mathrm{H}), 2.07,2.05(\times 2), 2.01,1.99(5 \mathrm{~s}, 15 \mathrm{H}$, $\mathrm{CH}_{3} \mathrm{CO}$ ) ppm. ${ }^{13} \mathrm{C} \mathrm{NMR}\left(100 \mathrm{MHz}, \mathrm{CDCl}_{3}\right): \delta=170.8,170.7,170.2$, $169.5(\times 2)\left(\mathrm{COCH}_{3}\right), 137.0,128.7,128.3(\times 2)$ (C-aromatic), $97.2(\mathrm{C}-$ 1), $83.1\left(\mathrm{C}-1^{\prime}\right), 76.1\left(\mathrm{C}-5^{\prime}\right), 74.0\left(\mathrm{C}-3^{\prime}\right), 70.1\left(\mathrm{C}-2^{\prime}\right), 69.5\left(\mathrm{PhCH}_{2} \mathrm{O}\right)$, $68.4\left(\times 2, \mathrm{C}-5, \mathrm{C}-4^{\prime}\right), 65.5(\mathrm{C}-6), 64.4(\mathrm{C}-2), 62.1\left(\mathrm{C}^{\prime}{ }^{\prime}\right), 43.2(\mathrm{C}-4), 35.0$ (C-3), 20.9, 20.8, $20.7(\times 3)\left(\mathrm{COCH}_{3}\right)$ ppm. HRMS (ESI): calcd for $\mathrm{C}_{29} \mathrm{H}_{38} \mathrm{NaO}_{14} \mathrm{~S} 665.1874[\mathrm{M}+\mathrm{Na}]^{+}$; found 665.1875.

Benzyl 6-O-acetyl-3-deoxy-4-S-(2,3,4,6-tetra-O-acetyl- $\beta$-D-glucopyranosyl)-4-thio- $\alpha$-D-ribo-hexopyranoside (8). Next, the more polar product was isolated $\left(R_{\mathrm{f}}=0.19\right.$, pentane/EtOAc, $\left.1: 1\right)$ and identified as thiodisaccharide 8 (66 $\mathrm{mg}, 18 \%)$ and was obtained as a white solid, $\mathrm{mp}$ at $113.6{ }^{\circ} \mathrm{C}$ (dec.). $[\alpha]_{\mathrm{D}}^{25}=+30.4\left(c=1.0, \mathrm{CHCl}_{3}\right)$. ${ }^{1} \mathrm{H}$ NMR (400 MHz, $\left.\mathrm{CDCl}_{3}\right): \delta=7.38-7.30\left(\mathrm{~m}, 5 \mathrm{H}, \mathrm{PhCH}_{2} \mathrm{O}\right), 5.18$ $\left(\mathrm{t}, J_{2^{\prime}, 3^{\prime}}=J_{3^{\prime}, 4^{\prime}}=9.3 \mathrm{~Hz}, 1 \mathrm{H}, 3^{\prime}-\mathrm{H}\right), 5.03\left(\mathrm{t}, J_{3^{\prime}, 4^{\prime}}=J_{4^{\prime}, 5^{\prime}}=9.8 \mathrm{~Hz}, 1 \mathrm{H}\right.$, $\left.4^{\prime}-\mathrm{H}\right), 4.95\left(\mathrm{t}, J_{1^{\prime}, 2^{\prime}}=J_{2^{\prime}, 3^{\prime}}=9.5 \mathrm{~Hz}, 1 \mathrm{H}, 2^{\prime}-\mathrm{H}\right), 4.93\left(\mathrm{~d}, J_{1,2}=1.8 \mathrm{~Hz}\right.$, $1 \mathrm{H}, 1-\mathrm{H}), 4.75\left(\mathrm{~d}, J=11.7 \mathrm{~Hz}, 1 \mathrm{H}, \mathrm{PhCH}_{2} \mathrm{O}\right), 4.58\left(\mathrm{~d}, J_{1^{\prime}, 2^{\prime}}=\right.$ $10.3 \mathrm{~Hz}, 1 \mathrm{H}, 1^{\prime}-\mathrm{H}$ ), 4.55 (d, $J=11.8 \mathrm{~Hz}, 1 \mathrm{H}, \mathrm{PhCH}_{2} \mathrm{O}$ ), 4.45 (dd, $\left.J_{6 \mathrm{a}, 6 \mathrm{~b}}=11.9, J_{5,6 \mathrm{a}}=1.3 \mathrm{~Hz}, 1 \mathrm{H}, 6 \mathrm{a}-\mathrm{H}\right), 4.28\left(\mathrm{dd}, J_{6 \mathrm{a}, 6 \mathrm{~b}}=12.0, J_{5,6 \mathrm{~b}}=\right.$ $5.4 \mathrm{~Hz}, 1 \mathrm{H}, 6 \mathrm{~b}-\mathrm{H}), 4.16\left(\mathrm{dd}, J_{6^{\prime} \mathrm{a}, 6^{\prime} \mathrm{b}}=12.1, J_{5^{\prime}, 6^{\prime} \mathrm{a}}=5.1 \mathrm{~Hz}, 1 \mathrm{H}, 6^{\prime} \mathrm{a}-\right.$ $\mathrm{H}), 4.05$ (dd, $J_{6^{\prime} \mathrm{a}, 6^{\prime} \mathrm{b}}=12.4, J_{5^{\prime}, 6^{\prime} \mathrm{b}}=1.9 \mathrm{~Hz}, 1 \mathrm{H}, 6^{\prime} \mathrm{b}-\mathrm{H}$ ), 3.80 (ddd, $\left.J_{4,5}=11.0, J_{5,6 \mathrm{~b}}=5.4, J_{5,6 \mathrm{a}}=1.4 \mathrm{~Hz}, 1 \mathrm{H}, 5-\mathrm{H}\right), 3.75(\mathrm{~m}, 1 \mathrm{H}, 2-\mathrm{H})$, $3.59\left(\mathrm{ddd}, J_{4^{\prime}, 5^{\prime}}=9.5, J_{5^{\prime}, 6^{\prime} \mathrm{a}}=4.7, J_{5^{\prime}, 6^{\prime} \mathrm{b}} 2.0 \mathrm{~Hz}, 1 \mathrm{H}, 5^{\prime}-\mathrm{H}\right), 2.90(\mathrm{td}$, $\left.J_{3 \mathrm{~b}, 4}=J_{4,5}=12.8, J_{3 \mathrm{a}, 4}=3.9 \mathrm{~Hz}, 1 \mathrm{H}, 4-\mathrm{H}\right), 2.26\left(\mathrm{dt}, J_{3 \mathrm{a}, 3 \mathrm{~b}}=11.8\right.$, $\left.J_{2,3 \mathrm{a}}=J_{3 \mathrm{a}, 4}=4.3 \mathrm{~Hz}, 1 \mathrm{H}, 3 \mathrm{a}-\mathrm{H}\right), 2.10,2.07,2.03,2.01,1.99(5 \mathrm{~s}, 15 \mathrm{H}$, $\left.\mathrm{CH}_{3} \mathrm{CO}\right), 1.88\left(\mathrm{q}, J_{2,3 \mathrm{~b}}=J_{3 \mathrm{a}, 3 \mathrm{~b}}=J_{3 \mathrm{~b}, 4}=12.3 \mathrm{~Hz}, 1 \mathrm{H}, 3 \mathrm{~b}-\mathrm{H}\right) \mathrm{ppm} .{ }^{13} \mathrm{C}$ NMR $\left(100 \mathrm{MHz}, \mathrm{CDCl}_{3}\right): \delta=170.7,170.6,170.2,169.4(\times 2)$ $\left(\mathrm{COCH}_{3}\right), 137.1,128.7,128.3,128.2$ (C-aromatic), 97.1 (C-1), 82.8 $\left(\mathrm{C}-1^{\prime}\right), 75.9\left(\mathrm{C}^{\prime} 5^{\prime}\right), 73.8\left(\mathrm{C}-3^{\prime}\right), 70.2(\mathrm{C}-5), 70.1\left(\mathrm{C}-2^{\prime}\right), 69.7\left(\mathrm{PhCH}_{2} \mathrm{O}\right)$, 68.2 (C-4'), 67.8 (C-2), 64.2 (C-6), 62.1 (C-6'), 39.8 (C-4), 35.9 (C-3), 21.0, 20.8, $20.7(\times 3)\left(\mathrm{COCH}_{3}\right)$ ppm. HRMS (ESI): calcd for $\mathrm{C}_{29} \mathrm{H}_{38} \mathrm{NaO}_{14} \mathrm{~S} 665.1874[\mathrm{M}+\mathrm{Na}]^{+}$; found 665.1872.

\section{Michael addition of thioaldose 4 to enone 3}

Benzyl 3-deoxy-6-O-(tert-butyldimethylsilyl)-4-S-(2,3,4,6tetra- $O$-acetyl- $\beta$-D-glucopyranosyl)-4-thio- $\alpha$-D-lyxo-hexopyranoside (10) and benzyl 3-deoxy-6-O-(tert-butyldimethylsilyl)-4-S-(2,3,4,6tetra- $O$-acetyl- $\beta$-D-glucopyranosyl)-4-thio- $\alpha$-D-ribo-hexopyranoside (11). The first fraction isolated from the column was in fact a mixture of two disaccharides $\left(R_{\mathrm{f}}=0.70\right.$, pentane/EtOAc, $\left.1: 1\right)$. 
They were identified as 10 and $11(235 \mathrm{mg}, 44 \%$, ratio 10/11 3.3 : 1.0). ${ }^{1} \mathrm{H} \mathrm{NMR}\left(400 \mathrm{MHz}, \mathrm{CDCl}_{3}\right.$ ) data for disaccharide 10: $\delta=$ 7.37-7.28 (m, 5H, $\mathrm{PhCH}_{2} \mathrm{O}$ overlapping with $\mathrm{PhCH}_{2} \mathrm{O}$ of 11), 5.23 $\left(\mathrm{t}, J_{2^{\prime}, 3^{\prime}}=J_{3^{\prime}, 4^{\prime}}=9.3 \mathrm{~Hz}, 1 \mathrm{H}, 3^{\prime}-\mathrm{H}\right), 5.09\left(\mathrm{t}, J_{3^{\prime}, 4^{\prime}}=J_{4^{\prime}, 5^{\prime}}=9.8 \mathrm{~Hz}, 1 \mathrm{H}\right.$, $\left.4^{\prime}-\mathrm{H}\right), 5.03\left(\mathrm{t}, J_{1^{\prime}, 2^{\prime}}=J_{2^{\prime}, 3^{\prime}}=9.8 \mathrm{~Hz}, 1 \mathrm{H}, 2^{\prime}-\mathrm{H}\right.$ overlapping with $4^{\prime}-\mathrm{H}$ of 11), 4.85 (br. s, $1 \mathrm{H}, 1-\mathrm{H}), 4.76$ (d, $\left.J=11.7 \mathrm{~Hz}, 1 \mathrm{H}, \mathrm{PhCH}_{2} \mathrm{O}\right), 4.71$ $\left(\mathrm{d}, J_{1^{\prime}, 2^{\prime}}=10.0 \mathrm{~Hz}, 1 \mathrm{H}, 1^{\prime}-\mathrm{H}\right), 4.51$ (d, $\left.J=11.7 \mathrm{~Hz}, 1 \mathrm{H}, \mathrm{PhCH}_{2} \mathrm{O}\right)$, $4.26(\mathrm{~m}, 1 \mathrm{H}, 5-\mathrm{H}), 4.23\left(\mathrm{dd}, J_{6^{\prime} \mathrm{a}, 6^{\prime} \mathrm{b}}=12.5, J_{5^{\prime}, 6^{\prime} \mathrm{a}}=4.8 \mathrm{~Hz}, 1 \mathrm{H}, 6^{\prime} \mathrm{a}-\right.$ $\mathrm{H}), 4.09\left(\mathrm{dd}, J_{6^{\prime} \mathrm{a}, 6^{\prime} \mathrm{b}}=12.4, J_{5^{\prime}, 6^{\prime} \mathrm{b}}=2.2 \mathrm{~Hz}, 1 \mathrm{H}, 6^{\prime} \mathrm{b}-\mathrm{H}\right), 3.76-3.64$ (m, 4H, 6a-H, 6b-H, 5'-H, 2-H overlapping with 2-H of 11), 3.36 (br. $\mathrm{d}, J=2.5 \mathrm{~Hz}, 1 \mathrm{H}, 4-\mathrm{H}), 2.26(\mathrm{~m}, 2 \mathrm{H}, 3 \mathrm{a}-\mathrm{H}, 3 \mathrm{~b}-\mathrm{H}$ overlapping with 3a-H of 11), 2.05-1.98 (4 s, $12 \mathrm{H}, \mathrm{CH}_{3} \mathrm{CO}$ overlapping with $\mathrm{CH}_{3} \mathrm{CO}$ of 11), $0.88\left(\mathrm{~s}, 9 \mathrm{H}, \mathrm{Si}\left(\mathrm{CH}_{3}\right)_{2} \mathrm{C}\left(\mathrm{CH}_{3}\right)_{3}\right), 0.08,0.07(2 \mathrm{~s}, 6 \mathrm{H}$, $\mathrm{Si}\left(\mathrm{CH}_{3}\right)_{2} \mathrm{C}\left(\mathrm{CH}_{3}\right)_{3}$ overlapping with $\mathrm{Si}\left(\mathrm{CH}_{3}\right)_{2} \mathrm{C}\left(\mathrm{CH}_{3}\right)_{3}$ of 11) ppm. ${ }^{13} \mathrm{C} \mathrm{NMR}\left(\mathrm{CDCl}_{3}, 100.0 \mathrm{MHz}\right)$ data for isomer 10: $\delta=170.6,170.2$, 169.5, 169.4 ( $\left.\mathrm{CH}_{3} \mathrm{CO}\right), 137.4,128.6,128.3,128.0$ (C-aromatic), $100.0(\mathrm{C}-1), 81.6\left(\mathrm{C}-1^{\prime}\right), 76.1\left(\mathrm{C}-5^{\prime}\right), 74.0\left(\mathrm{C}-3^{\prime}\right.$ overlapping with $\mathrm{C}-$ $3^{\prime}$ of 11), 71.1 (C-5), $70.2\left(\mathrm{C}-2^{\prime}\right), 69.0\left(\mathrm{PhCH}_{2} \mathrm{O}\right), 68.3\left(\mathrm{C}-4^{\prime}\right), 67.5$ (C2), 64.3 (C-6), 62.1 (C6'), 38.8 (C-4), $30.2(\mathrm{C}-3), 26.0\left(\mathrm{Si}\left(\mathrm{CH}_{3}\right)_{2^{-}}\right.$ $\left.\mathrm{C}\left(\mathrm{CH}_{3}\right)_{3}\right), 20.8-20.6\left(\mathrm{CH}_{3} \mathrm{CO}\right), 18.3\left(\mathrm{Si}\left(\mathrm{CH}_{3}\right)_{2} \mathrm{C}\left(\mathrm{CH}_{3}\right)_{3}\right),-5.2,-5.3$ $\left(\mathrm{Si}\left(\mathrm{CH}_{3}\right)_{2} \mathrm{C}\left(\mathrm{CH}_{3}\right)_{3}\right)$ ppm. ${ }^{1} \mathrm{H} \mathrm{NMR}\left(400 \mathrm{MHz}, \mathrm{CDCl}_{3}\right)$ data for disaccharide 11: $\delta=7.37-7.28\left(\mathrm{~m}, 5 \mathrm{H}, \mathrm{PhCH}_{2} \mathrm{O}\right.$ overlapping with $\mathrm{PhCH}_{2} \mathrm{O}$ of 10), $5.15\left(\mathrm{t}, J_{2^{\prime}, 3^{\prime}}=J_{3^{\prime}, 4^{\prime}}=9.3 \mathrm{~Hz}, 1 \mathrm{H}, 3^{\prime}-\mathrm{H}\right), 5.03\left(\mathrm{t}, J_{3^{\prime}, 4^{\prime}}\right.$ $=J_{4^{\prime}, 5^{\prime}}=9.6 \mathrm{~Hz}, 1 \mathrm{H}, 4^{\prime}-\mathrm{H}$ overlapping with $2^{\prime}-\mathrm{H}$ of 10), $4.93(\mathrm{dd}$, $\left.J_{1^{\prime}, 2^{\prime}}=10.1, J_{2^{\prime}, 3^{\prime}}=9.4 \mathrm{~Hz}, 2^{\prime}-\mathrm{H}\right), 4.89\left(\mathrm{~d}, J_{1,2}=3.5 \mathrm{~Hz}, 1 \mathrm{H}, 1-\mathrm{H}\right)$, $4.76\left(\mathrm{~d}, J_{1^{\prime}, 2^{\prime}}=10.2 \mathrm{~Hz}, 1 \mathrm{H}, 1^{\prime}-\mathrm{H}\right), 4.73(\mathrm{~d}, J=9.9 \mathrm{~Hz}, 1 \mathrm{H}$, $\mathrm{PhCH}_{2} \mathrm{O}$ ), 4.54 (d, $\left.J=9.9 \mathrm{~Hz}, 1 \mathrm{H}, \mathrm{PhCH}_{2} \mathrm{O}\right), 4.18\left(\mathrm{dd}, J_{6^{\prime} \mathrm{a}, 6^{\prime} \mathrm{b}}=\right.$ $\left.12.4, J_{5^{\prime}, 6^{\prime} \mathrm{a}}=5.1 \mathrm{~Hz}, 1 \mathrm{H}, 6^{\prime} \mathrm{a}-\mathrm{H}\right), 4.05\left(\mathrm{dd}, J_{6^{\prime} \mathrm{a}, 6^{\prime} \mathrm{b}}=12.5, J_{5^{\prime}, 6^{\prime} \mathrm{b}}=\right.$ $\left.2.1 \mathrm{~Hz}, 1 \mathrm{H}, 6^{\prime} \mathrm{b}-\mathrm{H}\right), 3.93$ (dd, $\left.J_{6 \mathrm{a}, 6 \mathrm{~b}}=11.5, J_{5,6 \mathrm{a}}=3.7 \mathrm{~Hz}, 1 \mathrm{H}, 6 \mathrm{a}-\mathrm{H}\right)$, $3.79\left(\mathrm{dd}, J_{6 \mathrm{a}, 6 \mathrm{~b}}=11.3, J_{5,6 \mathrm{a}}=0.8 \mathrm{~Hz}, 1 \mathrm{H}, 6 \mathrm{~b}-\mathrm{H}\right), 3.76-3.64(\mathrm{~m}, 1 \mathrm{H}$, 2-H, overlapping with $6 \mathrm{a}-\mathrm{H}, 6 \mathrm{~b}-\mathrm{H}, 5^{\prime}-\mathrm{H}, 2 \mathrm{H}$ of 10 ), 3.58 (ddd, $J_{4^{\prime}, 5^{\prime}}$ $\left.=10.0, J_{5^{\prime}, 6^{\prime} \mathrm{a}}=5.1, J_{5^{\prime}, 6^{\prime} \mathrm{b}}=2.2 \mathrm{~Hz}, 1 \mathrm{H}, 5^{\prime}-\mathrm{H}\right), 3.52\left(\mathrm{br} . \mathrm{dd}, J_{4,5}=\right.$ $\left.10.8, J_{5,6 \mathrm{~b}}=1.9 \mathrm{~Hz}, 1 \mathrm{H}, 5-\mathrm{H}\right), 3.01\left(\mathrm{ddd}, J_{3 \mathrm{~b}, 4}=13.5, J_{4,5}=11.1\right.$, $\left.J_{3 \mathrm{a}, 4}=4.2 \mathrm{~Hz}, 1 \mathrm{H}, 4-\mathrm{H}\right), 2.26(\mathrm{~m}, 1 \mathrm{H}, 3 \mathrm{a}-\mathrm{H}$ overlapping with $3 \mathrm{a}-\mathrm{H}$ and $3 \mathrm{~b}-\mathrm{H}$ of 10), 2.05-1.98 (4 s, $12 \mathrm{H}, \mathrm{CH}_{3} \mathrm{CO}$ overlapping with $\mathrm{CH}_{3} \mathrm{CO}$ of 10), 1.83 (q, $J_{2,3 \mathrm{~b}}=J_{3 \mathrm{a}, 3 \mathrm{~b}}=J_{3 \mathrm{~b}, 4}=12.4 \mathrm{~Hz}, 1 \mathrm{H}, 3 \mathrm{~b}-\mathrm{H}$ ), 0.91 (s, 9H, $\left.\mathrm{Si}\left(\mathrm{CH}_{3}\right)_{2} \mathrm{C}\left(\mathrm{CH}_{3}\right)_{3}\right), 0.09,0.07$ (2s, 6H, $\mathrm{Si}\left(\mathrm{CH}_{3}\right)_{2^{-}}$ $\mathrm{C}\left(\mathrm{CH}_{3}\right)_{3}$ overlapping with $\mathrm{Si}\left(\mathrm{CH}_{3}\right)_{2} \mathrm{C}\left(\mathrm{CH}_{3}\right)_{3}$ of 10$) \mathrm{ppm} .{ }^{13} \mathrm{C} \mathrm{NMR}$ $\left(\mathrm{CDCl}_{3}, 100.0 \mathrm{MHz}\right)$ data for isomer 11: $\delta=170.7,170.2,169.5$, $169.3\left(\mathrm{CH}_{3} \mathrm{CO}\right), 137.5,128.6,128.1,128.0$ (C-aromatic), 97.2 (C-1), $83.3\left(\mathrm{C}-1^{\prime}\right), 75.8\left(\mathrm{C}-5^{\prime}\right), 74.0\left(\mathrm{C}-3^{\prime}\right.$ overlapping with $\mathrm{C}-3^{\prime}$ of 10), 73.2

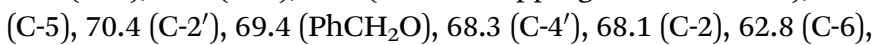
$62.2\left(\mathrm{C6}^{\prime}\right), 39.1(\mathrm{C}-4), 35.7(\mathrm{C}-3), 26.1\left(\mathrm{Si}\left(\mathrm{CH}_{3}\right)_{2} \mathrm{C}\left(\mathrm{CH}_{3}\right)_{3}\right), 20.8-20.6$ $\left(\mathrm{CH}_{3} \mathrm{CO}\right), 18.5\left(\mathrm{Si}\left(\mathrm{CH}_{3}\right)_{2} \mathrm{C}\left(\mathrm{CH}_{3}\right)_{3}\right),-4.9,-5.1\left(\mathrm{Si}\left(\mathrm{CH}_{3}\right)_{2} \mathrm{C}\left(\mathrm{CH}_{3}\right)_{3}\right)-$ ppm. HRMS (ESI): calcd for $\mathrm{C}_{33} \mathrm{H}_{50} \mathrm{NaO}_{13} \mathrm{SSi} 737.2634[\mathrm{M}+\mathrm{Na}]^{+}$; found 737.2661.

Benzyl 3-deoxy-6-O-(tert-butyldimethylsilyl)-4-S-(2,3,4,6-tetra$O$-acetyl- $\beta$-D-glucopyranosyl)-4-thio- $\alpha$-D-xylo-hexopyranoside (9). The second fraction of the column afforded the more polar compound $\left(R_{\mathrm{f}}=0.60\right.$, pentane/EtOAc, $\left.1: 1\right)$, which was obtained as a colourless syrupy and identified as thiodisaccharide 9 (168 mg, 31\%). $[\alpha]_{\mathrm{D}}^{20}=+16.8\left(c=1.1, \mathrm{CHCl}_{3}\right) .{ }^{1} \mathrm{H}$ NMR $(400 \mathrm{MHz}$, $\left.\mathrm{CDCl}_{3}\right): \delta=7.36-7.28\left(\mathrm{~m}, 5 \mathrm{H}, \mathrm{PhCH}_{2} \mathrm{O}\right), 5.19\left(\mathrm{t}, J_{2^{\prime}, 3^{\prime}}=J_{3^{\prime}, 4^{\prime}}=\right.$ $\left.9.3 \mathrm{~Hz}, 1 \mathrm{H}, 3^{\prime}-\mathrm{H}\right), 5.07\left(\mathrm{t}, J_{3^{\prime}, 4^{\prime}}=J_{4^{\prime}, 5^{\prime}}=9.7 \mathrm{~Hz}, 1 \mathrm{H}, 4^{\prime}-\mathrm{H}\right), 5.00(\mathrm{t}$, $\left.J_{1^{\prime}, 2^{\prime}}=J_{2^{\prime}, 3^{\prime}}=9.6 \mathrm{~Hz}, 1 \mathrm{H}, 2^{\prime}-\mathrm{H}\right), 4.89\left(\mathrm{~d}, J_{1,2}=3.7 \mathrm{~Hz}, 1 \mathrm{H}, 1-\mathrm{H}\right), 4.79$ $\left(\mathrm{d}, J=11.6 \mathrm{~Hz}, 1 \mathrm{H}, \mathrm{PhCH}_{2} \mathrm{O}\right), 4.58\left(\mathrm{~d}, J_{1^{\prime}, 2^{\prime}}=10.1 \mathrm{~Hz}, 1 \mathrm{H}, 1^{\prime}-\mathrm{H}\right)$, $4.51\left(\mathrm{~d}, J=11.5 \mathrm{~Hz}, 1 \mathrm{H}, \mathrm{PhCH}_{2} \mathrm{O}\right), 4.21\left(\mathrm{dd}, J_{6^{\prime} \mathrm{a}, 6^{\prime} \mathrm{b}}=12.4, J_{5^{\prime}, 6^{\prime} \mathrm{a}}=\right.$ $\left.4.7 \mathrm{~Hz}, 1 \mathrm{H}, 6^{\prime} \mathrm{a}-\mathrm{H}\right), 4.11-4.06$ (m, 3H, 6' b-H, 5- H, 2-H), $3.67(\mathrm{~m}, 2 \mathrm{H}$, $6 \mathrm{a}-\mathrm{H}, 6 \mathrm{~b}-\mathrm{H}), 3.64\left(\mathrm{ddd}, J_{4^{\prime}, 5^{\prime}}=9.7, J_{5^{\prime}, 6^{\prime} \mathrm{a}}=4.6, J_{5^{\prime}, 6^{\prime} \mathrm{b}}=2.4 \mathrm{~Hz}, 1 \mathrm{H}\right.$, $5^{\prime}-\mathrm{H}$ ), 3.34 (br. d, $J=2.0 \mathrm{~Hz}, 1 \mathrm{H}, 4-\mathrm{H}$ ), 2.15 (dt, $J_{3 \mathrm{a}, 3 \mathrm{~b}}=11.7, J_{2,3 \mathrm{a}}=$ $\left.J_{3 \mathrm{a}, 4}=3.3 \mathrm{~Hz}, 1 \mathrm{H}, 3 \mathrm{a}-\mathrm{H}\right), 2.05,2.03,2.00,1.98\left(4 \mathrm{~s}, 13 \mathrm{H}, \mathrm{CH}_{3} \mathrm{CO}\right.$ overlapping with $3 \mathrm{~b}-\mathrm{H}), 0.88\left(\mathrm{~s}, 9 \mathrm{H}, \mathrm{Si}\left(\mathrm{CH}_{3}\right)_{2} \mathrm{C}\left(\mathrm{CH}_{3}\right)_{3}\right), 0.07,0.06$ (2s, $\left.6 \mathrm{H}, \mathrm{Si}\left(\mathrm{CH}_{3}\right)_{2} \mathrm{C}\left(\mathrm{CH}_{3}\right)_{3}\right)$ ppm. ${ }^{13} \mathrm{C} \mathrm{NMR}\left(100 \mathrm{MHz}, \mathrm{CDCl}_{3}\right): \delta=$ 170.7, 170.2, 169.5, $169.4\left(\mathrm{COCH}_{3}\right), 137.3,128.6,128.3,128.1$ (Caromatic), 97.1 (C-1), $82.7\left(\mathrm{C}-1^{\prime}\right), 76.0\left(\mathrm{C}^{\prime} 5^{\prime}\right), 74.0\left(\mathrm{C}-3^{\prime}\right), 71.3$ (C5), $70.4\left(\mathrm{C}-2^{\prime}\right), 69.1\left(\mathrm{PhCH}_{2} \mathrm{O}\right), 68.3\left(\mathrm{C}-4^{\prime}\right), 64.6(\mathrm{C}-2), 64.4$ (C-6), $\left.62.1\left(\mathrm{C}^{\prime}\right)^{\prime}\right), 42.8$ (C-4), $34.5(\mathrm{C}-3), 26.0\left(\mathrm{Si}\left(\mathrm{CH}_{3}\right)_{2} \mathrm{C}\left(\mathrm{CH}_{3}\right)_{3}\right), 20.8$, 20.7, $20.6(\times 2)\left(\mathrm{COCH}_{3}\right), 18.3\left(\mathrm{Si}\left(\mathrm{CH}_{3}\right)_{2} \mathrm{C}\left(\mathrm{CH}_{3}\right)_{3}\right),-5.2(\times 2)$ $\left(\mathrm{Si}\left(\mathrm{CH}_{3}\right)_{2} \mathrm{C}\left(\mathrm{CH}_{3}\right)_{3}\right)$ ppm. HRMS (ESI): calcd for $\mathrm{C}_{33} \mathrm{H}_{50} \mathrm{NaO}_{13} \mathrm{SSi}$ $737.2634[\mathrm{M}+\mathrm{Na}]^{+}$; found 737.2623.

\section{General procedure for the $\boldsymbol{O}$-acetylation of thiodisaccharides}

To a solution of thiodisaccaride $(0.16 \mathrm{mmol})$ in pyridine $(1 \mathrm{~mL})$ was added dropwise $\mathrm{Ac}_{2} \mathrm{O}(1 \mathrm{~mL})$. The reaction was stirred at room temperature for $3 \mathrm{~h}$. Then, the mixture was cooled in an ice/water bath and $\mathrm{MeOH}$ was added dropwise $(1 \mathrm{~mL})$ and stirred for $30 \mathrm{~min}$. The evaporation of the solvent followed by co-evaporation with toluene $(3 \times 1 \mathrm{~mL})$ afforded the desired pure product.

Benzyl 3-deoxy-2,6-di-O-acetyl-4- $S$-(2,3,4,6-tetra- $O$-acetyl- $\beta$-Dglucopyranosyl)-4-thio- $\alpha$-D-xylo-hexopyranoside (12). The disaccharide 6 was $O$-acetylated to afford a $12(121 \mathrm{mg}, 98 \%)$ as a white solid, $\mathrm{mp}$ at $110{ }^{\circ} \mathrm{C}$ (dec.). $R_{\mathrm{f}}=0.53$ (pentane/EtOAc, $1: 1) .[\alpha]_{\mathrm{D}}^{25}=+28.5\left(c=1.2, \mathrm{CHCl}_{3}\right) .{ }^{1} \mathrm{H}$ NMR $(400 \mathrm{MHz}$, $\left.\mathrm{CDCl}_{3}\right): \delta=7.36-7.29\left(\mathrm{~m}, 5 \mathrm{H}, \mathrm{PhCH}_{2} \mathrm{O}\right), 5.21\left(\mathrm{~m}, 2 \mathrm{H}, 2-\mathrm{H}, 3^{\prime}-\mathrm{H}\right)$, $5.08\left(\mathrm{t}, J_{3^{\prime}, 4^{\prime}}=J_{4^{\prime}, 5^{\prime}} 9.7 \mathrm{~Hz}, 1 \mathrm{H}, 4^{\prime}-\mathrm{H}\right), 5.01\left(\mathrm{t}, J_{1^{\prime}, 2^{\prime}}=J_{2^{\prime}, 3^{\prime}}=9.6 \mathrm{~Hz}\right.$, $\left.1 \mathrm{H}, 2^{\prime}-\mathrm{H}\right), 5.01\left(\mathrm{~d}, J_{1,2}=3.2 \mathrm{~Hz}, 1 \mathrm{H}, 1-\mathrm{H}\right), 4.74(\mathrm{~d}, J=12.0 \mathrm{~Hz}, 1 \mathrm{H}$, $\left.\mathrm{PhCH}_{2} \mathrm{O}\right), 4.61\left(\mathrm{~d}, J_{1^{\prime}, 2^{\prime}}=10.0 \mathrm{~Hz}, 1 \mathrm{H}, 1^{\prime}-\mathrm{H}\right), 4.52$ (d, $J=12.0 \mathrm{~Hz}$, $\left.1 \mathrm{H}, \mathrm{PhCH}_{2} \mathrm{O}\right), 4.36(\mathrm{~m}, 1 \mathrm{H}, 5-\mathrm{H}), 4.21\left(\mathrm{dd}, J_{6^{\prime} \mathrm{a}, 6^{\prime} \mathrm{b}}=12.5, J_{5^{\prime}, 6^{\prime} \mathrm{a}}=\right.$ $\left.4.6 \mathrm{~Hz}, 1 \mathrm{H}, 6^{\prime} \mathrm{a}-\mathrm{H}\right), 4.16(\mathrm{~m}, 2 \mathrm{H}, 6 \mathrm{a}-\mathrm{H}, 6 \mathrm{~b}-\mathrm{H}), 4.13\left(\mathrm{dd}, J_{6^{\prime} \mathrm{a}, 6^{\prime} \mathrm{b}}=\right.$ $\left.12.5, J_{5^{\prime}, 6^{\prime} \mathrm{b}}=2.3 \mathrm{~Hz}, 1 \mathrm{H}, 6^{\prime} \mathrm{b}-\mathrm{H}\right), 3.67\left(\mathrm{ddd}, J_{4^{\prime}, 5^{\prime}}=9.9, J_{5^{\prime}, 6^{\prime} \mathrm{a}}=\right.$ $4.4, J_{5^{\prime}, 6^{\prime} \mathrm{b}}=2.4 \mathrm{~Hz}, 1 \mathrm{H}, 5^{\prime}-\mathrm{H}$ ), 3.39 (br. d, $J=2.1 \mathrm{~Hz}, 1 \mathrm{H}, 4-\mathrm{H}$ ), $2.34\left(\mathrm{td}, J_{2,3 \mathrm{a}}=J_{3 \mathrm{a}, 3 \mathrm{~b}}=12.6, J_{3 \mathrm{a}, 4}=3.6 \mathrm{~Hz}, 1 \mathrm{H}, 3 \mathrm{a}-\mathrm{H}\right), 2.14(\mathrm{~m}$, 1H, 3b-H), 2.07, $2.06(\times 2), 2.03,2.01,1.99\left(\mathrm{COCH}_{3}\right) \mathrm{ppm} .{ }^{13} \mathrm{C}$ NMR (100 MHz, $\left.\mathrm{CDCl}_{3}\right): \delta=170.7,170.6,170.2(\times 2), 169.7$, $169.4\left(\mathrm{COCH}_{3}\right), 137.3,128.6,128.1,128.0$ (C-aromatic), 94.9 (C1), $82.8\left(\mathrm{C}-1^{\prime}\right), 76.1\left(\mathrm{C}-5^{\prime}\right), 73.9\left(\mathrm{C}-3^{\prime}\right), 70.0\left(\mathrm{C}-2^{\prime}\right), 69.2\left(\mathrm{PhCH}_{2} \mathrm{O}\right)$, $68.3\left(\times 2, \mathrm{C}^{\prime} \mathbf{4}^{\prime}, \mathrm{C}-5\right), 66.9$ (C-2), $65.4(\mathrm{C}-6), 62.0\left(\mathrm{C}-6^{\prime}\right), 42.9(\mathrm{C}-4)$, 30.9 (C-3), 21.1, 20.9, 20.8, $20.7(\times 3)\left(\mathrm{COCH}_{3}\right)$. HRMS (ESI): calcd for $\mathrm{C}_{31} \mathrm{H}_{40} \mathrm{NaO}_{15} \mathrm{~S} 707.1980[\mathrm{M}+\mathrm{Na}]^{+}$; found 707.1959.

Benzyl 2-O-acetyl-3-deoxy-6-O-(tert-butyldimethylsilyl)-4-S$(2,3,4,6$-tetra- $O$-acetyl- $\beta$-D-glucopyranosyl)-4-thio- $\alpha$-D-xylo-hexopyranoside (13). The $O$-acetylation of compound 9 gave the thiodisaccharide $13(167 \mathrm{mg}, 100 \%)$ as a colourless syrup. $\left(R_{\mathrm{f}}=0.73\right.$, pentane/EtOAc, $1: 1) \cdot[\alpha]_{\mathrm{D}}^{20}=+21.5\left(c=1.0, \mathrm{CHCl}_{3}\right) \cdot{ }^{1} \mathrm{H}$ NMR $(400$ $\left.\mathrm{MHz}, \mathrm{CDCl}_{3}\right): \delta=7.34-7.28\left(\mathrm{~m}, 5 \mathrm{H}, \mathrm{PhCH}_{2} \mathrm{O}\right), 5.24(\mathrm{~m}, 1 \mathrm{H}, 2-\mathrm{H})$, $5.21\left(\mathrm{t}, J_{2^{\prime}, 3^{\prime}}=J_{3^{\prime}, 4^{\prime}}=9.4 \mathrm{~Hz}, 1 \mathrm{H}, 3^{\prime}-\mathrm{H}\right), 5.08\left(\mathrm{t}, J_{3^{\prime}, 4^{\prime}}=J_{4^{\prime}, 5^{\prime}}=\right.$ $\left.9.7 \mathrm{~Hz}, 1 \mathrm{H}, 4^{\prime}-\mathrm{H}\right), 5.01\left(\mathrm{t}, J_{1^{\prime}, 2^{\prime}}=J_{2^{\prime}, 3^{\prime}}=9.9 \mathrm{~Hz}, 1 \mathrm{H}, 2^{\prime}-\mathrm{H}\right), 4.98$ (d, $\left.J_{1,2}=3.3 \mathrm{~Hz}, 1 \mathrm{H}, 1-\mathrm{H}\right), 4.77\left(\mathrm{~d}, J=12.1 \mathrm{~Hz}, 1 \mathrm{H}, \mathrm{PhCH}_{2} \mathrm{O}\right), 4.60(\mathrm{~d}$, $\left.J_{1^{\prime}, 2^{\prime}}=10.1 \mathrm{~Hz}, 1 \mathrm{H}, 1^{\prime}-\mathrm{H}\right), 4.53\left(\mathrm{~d}, J=12.1 \mathrm{~Hz}, 1 \mathrm{H}, \mathrm{PhCH}_{2} \mathrm{O}\right), 4.22$ $\left(\mathrm{dd}, J_{6^{\prime} \mathrm{a}, 6^{\prime} \mathrm{b}}=12.3, J_{5^{\prime}, 6^{\prime} \mathrm{a}}=4.7 \mathrm{~Hz}, 1 \mathrm{H}, 6^{\prime} \mathrm{a}-\mathrm{H}\right), 4.20(\mathrm{~m}, 1 \mathrm{H}, 5-\mathrm{H})$, $4.09\left(\mathrm{dd}, J_{6^{\prime} \mathrm{a}, 6^{\prime} \mathrm{b}}=12.3, J_{5^{\prime}, 6^{\prime} \mathrm{b}}=2.2 \mathrm{~Hz}, 1 \mathrm{H}, 6^{\prime} \mathrm{b}-\mathrm{H}\right), 3.66\left(\mathrm{~m}, 3 \mathrm{H}, 5^{\prime}-\right.$ H, 6a-H, 6b-H), 3.41 (br. d, $J=2.1 \mathrm{~Hz}, 1 \mathrm{H}, 4-\mathrm{H}$ ), 2.31 (td, $J_{2,3 \mathrm{a}}=$ 
$\left.J_{3 \mathrm{a}, 3 \mathrm{~b}}=12.3, J_{3,4}=3.3 \mathrm{~Hz}, 1 \mathrm{H}, 3 \mathrm{a}-\mathrm{H}\right), 2.12(\mathrm{~m}, 1 \mathrm{H}, 3 \mathrm{~b}-\mathrm{H}), 2.06$, 2.05, 2.04, 2.01, $1.99\left(\mathrm{COCH}_{3}\right), 0.89\left(\mathrm{~s}, 9 \mathrm{H}, \mathrm{Si}\left(\mathrm{CH}_{3}\right)_{2} \mathrm{C}\left(\mathrm{CH}_{3}\right)_{3}\right), 0.08$, 0.07 (2s, 6H, Si $\left.\left(\mathrm{CH}_{3}\right)_{2} \mathrm{C}\left(\mathrm{CH}_{3}\right)_{3}\right) .{ }^{13} \mathrm{C} \mathrm{NMR}\left(100 \mathrm{MHz}, \mathrm{CDCl}_{3}\right): \delta=$ 170.6, 170.3, 170.2, 169.9, $169.5\left(\mathrm{COCH}_{3}\right), 137.5,128.5,128.0$, 127.9 (C-aromatic), 94.7 (C-1), $82.4\left(\mathrm{C}-1^{\prime}\right), 76.0\left(\mathrm{C}-5^{\prime}\right), 74.0\left(\mathrm{C}-3^{\prime}\right)$, 71.2 (C-5), 70.2 (C-2'), $68.9\left(\mathrm{OCH}_{2} \mathrm{Ph}\right), 68.4\left(\mathrm{C}-4^{\prime}\right), 67.2$ (C-2), 64.4 (C-6), 62.1 (C-6'), 42.5 (C-4), 30.3 (C-3), $26.0\left(\mathrm{Si}\left(\mathrm{CH}_{3}\right)_{2} \mathrm{C}\left(\mathrm{CH}_{3}\right)_{3}\right)$, 21.1, 20.8, $20.7(\times 3)\left(\mathrm{COCH}_{3}\right), 18.4\left(\mathrm{Si}\left(\mathrm{CH}_{3}\right)_{2} \mathrm{C}\left(\mathrm{CH}_{3}\right)_{3}\right),-5.2(\times 2$, $\left.\mathrm{Si}\left(\mathrm{CH}_{3}\right)_{2} \mathrm{C}\left(\mathrm{CH}_{3}\right)_{3}\right)$ ppm. HRMS (ESI): calcd for $\mathrm{C}_{35} \mathrm{H}_{52} \mathrm{NaO}_{14} \mathrm{SSi}$ $779.2739[\mathrm{M}+\mathrm{Na}]^{+}$; found 779.2721 .

\section{Desilylation reaction of thiodisaccharide 13}

Benzyl 2-O-acetyl-3-deoxy-4-S-(2,3,4,6-tetra-O-acetyl- $\beta$-D-glucopyranosyl)-4-thio- $\alpha$-D-xylo-hexopyranoside (14). To a solution containing thiodisaccharide $13(276 \mathrm{mg}, 0.365 \mathrm{mmol})$ in THF $(12.8 \mathrm{~mL})$ was added dropwise $1 \mathrm{M}$ TBAF in THF $(0.44 \mathrm{~mL})$. The mixture was stirred at room temperature for $3 \mathrm{~h}$, then the solvent was evaporated and the residue was dissolved in $50 \mathrm{~mL}$ of $\mathrm{CH}_{2} \mathrm{Cl}_{2}$. The resulting solution was washed with $\mathrm{H}_{2} \mathrm{O}(2 \times 25$ $\mathrm{mL})$, dried $\left(\mathrm{MgSO}_{4}\right)$, and filtered. Evaporation of the solvent afforded an oily residue that was purified by column chromatography with hexane/EtOAc $(4: 1 \rightarrow 1: 1)$ to give the thiodisaccharide $14(153 \mathrm{mg}, 65 \%)$ as a more polar product $\left(R_{\mathrm{f}}=\right.$ 0.29 , hexane/EtOAc, $1: 1)$, and a white solid, $\mathrm{mp}$ at $146^{\circ} \mathrm{C}$ (dec.) $[\alpha]_{\mathrm{D}}^{28}=+32.9\left(c=1.0, \mathrm{CHCl}_{3}\right) .{ }^{1} \mathrm{H}$ NMR $\left(500 \mathrm{MHz}, \mathrm{CDCl}_{3}\right): \delta=$ 7.35-7.27 (m, 5H, $\left.\mathrm{PhCH}_{2} \mathrm{O}\right), 5.21\left(\mathrm{t}, J_{2^{\prime}, 3^{\prime}}=J_{3^{\prime}, 4^{\prime}}=9.4 \mathrm{~Hz}, 1 \mathrm{H}, 3^{\prime}-\right.$ $\mathrm{H}), 5.10\left(\mathrm{ddd}, J_{2,3 \mathrm{a}}=12.0, J_{2,3 \mathrm{~b}}=4.6, J_{1,2}=3.8 \mathrm{~Hz}, 1 \mathrm{H}, 2-\mathrm{H}\right), 5.04$ $\left(\mathrm{dd}, J_{4^{\prime}, 5^{\prime}}=10.0, J_{3^{\prime}, 4^{\prime}}=9.6 \mathrm{~Hz}, 1 \mathrm{H}, 4^{\prime}-\mathrm{H}\right), 5.00\left(\mathrm{dd}, J_{1^{\prime}, 2^{\prime}}=10.0\right.$, $\left.J_{2^{\prime}, 3^{\prime}}=9.4 \mathrm{~Hz}, 1 \mathrm{H}, 2^{\prime}-\mathrm{H}\right), 4.96$ (br. d, $\left.J_{1,2}=3.6 \mathrm{~Hz}, 1 \mathrm{H}, 1-\mathrm{H}\right), 4.72$ $\left(\mathrm{d}, J=12.2 \mathrm{~Hz}, 1 \mathrm{H}, \mathrm{PhCH}_{2} \mathrm{O}\right), 4.58\left(\mathrm{~d}, J_{1^{\prime}, 2^{\prime}}=10.1 \mathrm{~Hz}, 1 \mathrm{H}, 1^{\prime}-\mathrm{H}\right)$, $4.54\left(\mathrm{~d}, J=12.2 \mathrm{~Hz}, 1 \mathrm{H}, \mathrm{PhCH}_{2} \mathrm{O}\right), 4.18(\mathrm{~m}, 1 \mathrm{H}, 5-\mathrm{H}), 4.14(\mathrm{~m}$, $2 \mathrm{H}, 6^{\prime} \mathrm{a}-\mathrm{H}, 6^{\prime} \mathrm{b}-\mathrm{H}$ ), 3.71 (dd, $J_{6 \mathrm{a}, 6 \mathrm{~b}}=11.6, J_{5,6 \mathrm{a}}=7.7 \mathrm{~Hz}, 1 \mathrm{H}, 6 \mathrm{a}-$ $\mathrm{H}), 3.70\left(\mathrm{~m}, 1 \mathrm{H}, 5^{\prime}-\mathrm{H}\right), 3.56\left(\mathrm{dd}, J_{6 \mathrm{a}, 6 \mathrm{~b}}=11.6, J_{5,6 \mathrm{~b}}=6.2 \mathrm{~Hz}\right.$, $1 \mathrm{H}, 6 \mathrm{~b}-\mathrm{H}), 3.39$ (br d, $J=2.5 \mathrm{~Hz}, 1 \mathrm{H}, 4-\mathrm{H}), 2.36\left(\mathrm{td}, J_{2,3 \mathrm{a}}=J_{3 \mathrm{a}, 3 \mathrm{~b}}=\right.$ $12.4, J_{3 \mathrm{a}, 4}=3.6 \mathrm{~Hz}, 1 \mathrm{H}, 3 \mathrm{a}-\mathrm{H}$ ), 2.17 (br. td, $J_{3 \mathrm{a}, 3 \mathrm{~b}}=12.8, J_{2,3 \mathrm{~b}}=$ $\left.J_{2,3 \mathrm{~b}}=3.8 \mathrm{~Hz}, 1 \mathrm{H}, 3 \mathrm{~b}-\mathrm{H}\right), 2.08,2.07,2.03,2.01,1.99\left(\mathrm{COCH}_{3}\right)-$ ppm. ${ }^{13} \mathrm{C} \mathrm{NMR}\left(125.7 \mathrm{MHz}, \mathrm{CDCl}_{3}\right): \delta=170.7,170.2(\times 2), 169.9$, 169.4 $\left(\mathrm{COCH}_{3}\right), 137.4,128.5,128.0(\times 2)$ (C-aromatic), $95.2(\mathrm{C}-1)$, $83.8\left(\mathrm{C}-1^{\prime}\right), 76.1\left(\mathrm{C}-5^{\prime}\right), 73.7\left(\mathrm{C}-3^{\prime}\right), 70.2\left(\mathrm{C}-2^{\prime}\right), 69.7(\mathrm{C}-5), 69.6$ $\left(\mathrm{PhCH}_{2} \mathrm{O}\right), 68.3\left(\mathrm{C}-4^{\prime}\right), 67.5(\mathrm{C}-2), 62.3(\mathrm{C}-6), 62.1\left(\mathrm{C}-6^{\prime}\right), 43.6(\mathrm{C}-$ 4), $31.3(\mathrm{C}-3), 21.1,20.8(\times 2), 20.7(\times 2)\left(\mathrm{COCH}_{3}\right)$. HRMS (ESI): calcd for $\mathrm{C}_{29} \mathrm{H}_{38} \mathrm{NaO}_{14} \mathrm{~S} 665.1875[\mathrm{M}+\mathrm{Na}]^{+}$; found 665.1885 .

General procedure for the oxidation reaction of $S$ - $(1 \rightarrow 4)$ thiodisaccharides (12-14) to sulfoxides (15-17)

A solution of $m \mathrm{CPBA}(77 \%, 32 \mathrm{mg}, 0.141 \mathrm{mmol})$ in $2 \mathrm{~mL}$ of dry $\mathrm{CH}_{2} \mathrm{Cl}_{2}$ was added dropwise to another solution of the thiodisaccharide $(0.072 \mathrm{mmol})$ in $2 \mathrm{~mL}$ of ethyl ether at $0{ }^{\circ} \mathrm{C}$. The reaction was allowed to reach room temperature and after $30 \mathrm{~min}$ of stirring was diluted with EtOAc $(30 \mathrm{~mL})$. To the mixture was added a solution of $\mathrm{NaHSO}_{3}$ (satd. aq.; $10 \mathrm{~mL}$ ) and stirred for $30 \mathrm{~min}$. The organic phase was separated and stirred with $\mathrm{NaHCO}_{3}$ (satd. aq.; $10 \mathrm{~mL}$ ) for $30 \mathrm{~min}$. The organic extract was washed with $\mathrm{NaHCO}_{3}$ (satd. aq.; $10 \mathrm{~mL}$ ) and brine $(10 \mathrm{~mL})$, dried $\left(\mathrm{MgSO}_{4}\right)$, and filtered. The evaporation of the solvent, followed by co-evaporation with $1: 1$ toluene/EtOH $(5 \times 10 \mathrm{~mL})$ afforded an oily residue that was purified by column chromatography with pentane/EtOAc $(3: 2 \rightarrow 1: 1)$ or $\mathrm{CH}_{2} \mathrm{Cl}_{2} /$ EtOAc $(8: 1 \rightarrow 4: 1)$, to give the diasteromeric mixture of sulfoxides, which in some cases could be separated.

\section{Oxidation reaction of thiodisaccharide 12 to sulfoxides $15 R$ and $15 S$}

Benzyl 3-deoxy-2,6-di- $O$-acetyl-4- $S$-(2,3,4,6-tetra- $O$-acetyl- $\beta$-Dglucopyranosyl)-4-thio- $\alpha$-D-xylo-hexopyranoside $\quad(R, S)$ - $S$-oxide $(\mathbf{1 5 R}, S)$. The oxidation reaction of the thiodisaccharide 12 gave the diasteromeric mixture of sulfoxides $15 R, S$ that could not be separated by column chromatography. The mixture $(42 \mathrm{mg}$, $74 \%$, ratio $R / S, 1.4: 1)$ showed a single spot by TLC $\left(R_{\mathrm{f}}=0.29\right.$, pentane/EtOAc, $1: 1)$. The isomer $15 R$ was obtained pure by the procedure described below; but the spectral data described for $15 S$ were obtained from the mixture $15 R, S .{ }^{1} \mathrm{H}$ NMR $(400 \mathrm{MHz}$, $\mathrm{CDCl}_{3}$ ) data for $\boldsymbol{S}$ isomer: $\delta=7.39-7.30\left(\mathrm{~m}, 5 \mathrm{H}, \mathrm{PhCH}_{2} \mathrm{O}\right.$ overlapping with $\mathrm{PhCH}_{2} \mathrm{O}$ of 15R), $5.43\left(\mathrm{~d}, J_{1^{\prime}, 2^{\prime}}=J_{2^{\prime}, 3^{\prime}}=9.4 \mathrm{~Hz}, 1 \mathrm{H}\right.$, $\left.2^{\prime}-\mathrm{H}\right), 5.28\left(\mathrm{t}, J_{2^{\prime}, 3^{\prime}}=J_{3^{\prime}, 4^{\prime}}=9.2 \mathrm{~Hz}, 1 \mathrm{H}, 3^{\prime}-\mathrm{H}\right), 5.22(\mathrm{~m}, 1 \mathrm{H}, 2-\mathrm{H})$, $5.20\left(\mathrm{~d}, J_{1,2}=1.6 \mathrm{~Hz}, 1 \mathrm{H}, 1-\mathrm{H}\right), 5.09\left(\mathrm{t}, J_{3^{\prime}, 4^{\prime}}=J_{4^{\prime}, 5^{\prime}}=9.7 \mathrm{~Hz}, 1 \mathrm{H}\right.$, $\left.4^{\prime}-\mathrm{H}\right), 4.74\left(\mathrm{~d}, J=11.9 \mathrm{~Hz}, 1 \mathrm{H}, \mathrm{PhCH}_{2} \mathrm{O}\right), 4.55-4.53(\mathrm{~m}, 2 \mathrm{H}$, $\mathrm{PhCH}_{2} \mathrm{O}, 5-\mathrm{H}$ overlapping with $1^{\prime}-\mathrm{H}$ of $\left.15 R\right), 4.32\left(\mathrm{~d}, J_{1^{\prime}, 2^{\prime}}=\right.$ $\left.9.7 \mathrm{~Hz}, 1 \mathrm{H}, 1^{\prime}-\mathrm{H}\right), 4.26-4.16\left(\mathrm{~m}, 4 \mathrm{H}, 6 \mathrm{a}-\mathrm{H}, 6 \mathrm{~b}-\mathrm{H}, 6^{\prime} \mathrm{a}-\mathrm{H}, 6^{\prime} \mathrm{b}-\mathrm{H}\right.$ overlapping with $6^{\prime} \mathrm{a}-\mathrm{H}, 6^{\prime} \mathrm{b}-\mathrm{H}$ of $\left.15 R\right), 3.79\left(\mathrm{~m}, 1 \mathrm{H}, 5^{\prime}-\mathrm{H}\right.$ overlapping with $5^{\prime}-\mathrm{H}$ of $\left.\mathbf{1 5 R}\right), 3.45(\mathrm{~m}, 1 \mathrm{H}, 4-\mathrm{H}), 2.50\left(\mathrm{ddd}, J_{3 \mathrm{a}, 3 \mathrm{~b}}=\right.$ $\left.13.3, J_{2,3 \mathrm{a}}=5.7, J_{3 \mathrm{a}, 4}=2.6 \mathrm{~Hz}, 1 \mathrm{H}, 3 \mathrm{a}-\mathrm{H}\right), 2.28(\mathrm{~m}, 1 \mathrm{H}, 3 \mathrm{~b}-\mathrm{H}$ overlapping with $3 \mathrm{a}-\mathrm{H}$ of $15 R), 2.09-2.01\left(6 \mathrm{~s}, 18 \mathrm{H}, \mathrm{COCH}_{3}\right.$ overlapping with $\mathrm{COCH}_{3}$ and $3 \mathrm{~b}-\mathrm{H}$ of $15 R$ ) ppm. ${ }^{13} \mathrm{C} \mathrm{NMR}$ $\left(\mathrm{CDCl}_{3}, 100.0 \mathrm{MHz}\right)$ data for $S$ isomer: $\delta=170.7-168.8\left(\mathrm{CH}_{3} \mathrm{CO}\right)$, 137.2, 128.6, 128.1, 128.0 (C-aromatic), 95.1 (C-1), 90.4 (C-1'), $77.0\left(\mathrm{C}-5^{\prime}\right), 73.4\left(\mathrm{C}-3^{\prime}\right), 69.9\left(\mathrm{OCH}_{2} \mathrm{Ph}\right), 68.6\left(\mathrm{C}-2^{\prime}\right), 67.7\left(\mathrm{C}-4^{\prime}\right)$, 66.5 (C-2), 66.2 (C-5), 63.7 (C-6), 61.6 (C-6'), 55.0 (C-4), 22.9 (C-3), 21.1-20.6 $\left(\mathrm{COCH}_{3}\right)$ ppm. HRMS (ESI): calcd for $\mathrm{C}_{31} \mathrm{H}_{41} \mathrm{O}_{16} \mathrm{~S}$ $701.2110[\mathrm{M}+\mathrm{H}]^{+}$; found 701.2085 .

Benzyl 3-deoxy-2,6-di- $O$-acetyl-4- $S$-(2,3,4,6-tetra- $O$-acetyl- $\beta$-Dglucopyranosyl)-4-thio- $\alpha$-D-xylo-hexopyranoside $\quad(R)-S$-oxide (15R). Compound $15 R$ was obtained as a single diastereoisomer starting from 16R. Thus, compound $16 \boldsymbol{R}$ (32 $\mathrm{mg}, 0.041 \mathrm{mmol})$ dissolved in THF $(1.5 \mathrm{~mL})$ and treated with a solution of TBAF $1 \mathrm{M}$ in THF $(50 \mu \mathrm{L})$. The mixture was stirred at room temperature for $2.5 \mathrm{~h}$, then the solvent was evaporated and the residue was dissolved in $\mathrm{CH}_{2} \mathrm{Cl}_{2}(50 \mathrm{~mL})$. The resulting solution was washed with $\mathrm{H}_{2} \mathrm{O}(2 \times 25 \mathrm{~mL})$, dried $\left(\mathrm{Na}_{2} \mathrm{SO}_{4}\right)$, and filtered. Evaporation of the solvent afforded a product that exhibited NMR data identical to that of sulfoxide $\mathbf{1 7} \boldsymbol{R}$ (see below). Acetylation of $17 \boldsymbol{R}$ (acetic anhydride/pyridine $1: 1,0.4 \mathrm{~mL}$ ) at room temperature for $2 \mathrm{~h}$ led, after column chromatography, to syrupy 15R (18 mg, 61\% from 16R). ${ }^{1} \mathrm{H}$ NMR (400 $\mathrm{MHz}, \mathrm{CDCl}_{3}$ ): $\delta=7.39-7.30\left(\mathrm{~m}, 5 \mathrm{H}, \mathrm{PhCH}_{2} \mathrm{O}\right), 5.47\left(\mathrm{t}, J_{1^{\prime}, 2^{\prime}}=J_{2^{\prime}, 3^{\prime}}=9.5 \mathrm{~Hz}, 1 \mathrm{H}\right.$, $\left.2^{\prime}-\mathrm{H}\right), 5.40\left(\mathrm{t}, J_{2^{\prime}, 3^{\prime}}=J_{3^{\prime}, 4^{\prime}}=9.2 \mathrm{~Hz}, 1 \mathrm{H}, 3^{\prime}-\mathrm{H}\right), 5.12\left(\mathrm{t}, J_{4^{\prime}, 5^{\prime}}=J_{3^{\prime}, 4^{\prime}}=\right.$ $\left.9.7 \mathrm{~Hz}, 1 \mathrm{H}, 4^{\prime}-\mathrm{H}\right), 5.08$ (d, $\left.J_{1,2}=3.3 \mathrm{~Hz}, 1 \mathrm{H}, 1-\mathrm{H}\right), 4.82(\mathrm{~d}, J=$ $\left.11.8 \mathrm{~Hz}, 1 \mathrm{H}, \mathrm{PhCH}_{2} \mathrm{O}\right), 4.70\left(\mathrm{dt}, J_{2,3 \mathrm{a}}=8.8, J_{1,2}=J_{2,3 \mathrm{~b}}=3.9 \mathrm{~Hz}\right.$, $1 \mathrm{H}, 2-\mathrm{H}), 4.66(\mathrm{~m}, 1 \mathrm{H}, 5-\mathrm{H}), 4.58\left(\mathrm{~d}, J=11.7 \mathrm{~Hz}, 1 \mathrm{H}, \mathrm{PhCH}_{2} \mathrm{O}\right)$, $4.56\left(\mathrm{~d}, J_{1^{\prime}, 2^{\prime}}=9.6 \mathrm{~Hz}, 1 \mathrm{H}, 1^{\prime}-\mathrm{H}\right), 4.46(\mathrm{~m}, 2 \mathrm{H}, 6 \mathrm{a}-\mathrm{H}, 6 \mathrm{~b}-\mathrm{H}), 4.23$ $\left(\mathrm{dd}, J_{6^{\prime} \mathrm{a}, 6^{\prime} \mathrm{b}}=12.4, J_{6^{\prime} \mathrm{a}, 5^{\prime}}=2.3 \mathrm{~Hz}, 1 \mathrm{H}, 6^{\prime} \mathrm{a}-\mathrm{H}\right), 4.17\left(\mathrm{dd}, J_{6^{\prime} \mathrm{a}, 6^{\prime} \mathrm{b}}=\right.$ $\left.12.5, J_{6^{\prime} \mathrm{b}, 5^{\prime}}=5.6 \mathrm{~Hz}, 1 \mathrm{H}, 6^{\prime} \mathrm{b}-\mathrm{H}\right) 3.80\left(\mathrm{ddd}, J_{4^{\prime}, 5^{\prime}}=9.9, J_{6^{\prime} \mathrm{b}, 5^{\prime}}=5.5\right.$, 
$\left.J_{6^{\prime} \mathrm{a}, 5^{\prime}}=2.3 \mathrm{~Hz}, 1 \mathrm{H}, 5^{\prime}-\mathrm{H}\right), 3.62($ br. s, $1 \mathrm{H}, 4-\mathrm{H}), 2.34\left(\mathrm{td}, J_{2,3 \mathrm{a}}=\right.$ $\left.J_{3 \mathrm{a}, 3 \mathrm{~b}}=13.6, J_{3 \mathrm{a}, 4}=3.9 \mathrm{~Hz}, 1 \mathrm{H}, 3 \mathrm{a}-\mathrm{H}\right), 2.08-2.02(6 \mathrm{~s}, 19 \mathrm{H}$, $\left.\mathrm{COCH}_{3}, 3 \mathrm{~b}-\mathrm{H}\right)$ ppm. ${ }^{13} \mathrm{C} \mathrm{NMR}\left(\mathrm{CDCl}_{3}, 100.0 \mathrm{MHz}\right): \delta=170.7-$ $168.8\left(\mathrm{CH}_{3} \mathrm{CO}\right), 136.8,128.7,128.3,128.1$ (C-aromatic), 94.9 (C1), $86.8\left(\mathrm{C}-1^{\prime}\right), 77.4\left(\mathrm{C}-5^{\prime}\right), 74.0\left(\mathrm{C}-3^{\prime}\right), 69.4\left(\mathrm{OCH}_{2} \mathrm{Ph}\right), 69.2(\mathrm{C}-5)$, $68.0\left(\mathrm{C}-4^{\prime}\right), 67.1(\mathrm{C}-2), 66.4\left(\mathrm{C}-2^{\prime}\right), 64.7$ (C-6), $62.1\left(\mathrm{C}-6^{\prime}\right), 58.8$ (C4), 25.9 (C-3), 21.0-20.6 $\left(\mathrm{COCH}_{3}\right) \mathrm{ppm}$.

\section{Oxidation reaction of thiodisaccaride 13 to sulfoxides $16 R$ and} $16 S$

Benzyl 2-O-acetyl-3-deoxy-6-O-(tert-butyldimethylsilyl)-4-S$(2,3,4,6$-tetra- $O$-acetyl- $\beta$-D-glucopyranosyl)-4-thio- $\alpha$-D-xylo-hexopyranoside $(R)$-S -oxide $(16 R)$. The major product of the oxidation of thiodisaccharide 13 was the sulfoxide $16 R(50 \mathrm{mg}, 59 \%)$ obtained as a white solid, $\mathrm{mp}$ at $166.2{ }^{\circ} \mathrm{C}$ (dec.). $R_{\mathrm{f}}=0.56, \mathrm{CH}_{2} \mathrm{Cl}_{2} /$ EtOAc $(4: 1) \cdot[\alpha]_{\mathrm{D}}^{25}=+25.4\left(c=1.0, \mathrm{CHCl}_{3}\right) \cdot{ }^{1} \mathrm{H} \mathrm{NMR}\left(500 \mathrm{MHz}, \mathrm{CDCl}_{3}\right)$ : $\delta=7.39-7.29\left(\mathrm{~m}, 5 \mathrm{H}, \mathrm{PhCH}_{2} \mathrm{O}\right), 5.46\left(\mathrm{t}, J_{1^{\prime}, 2^{\prime}}=J_{2^{\prime}, 3^{\prime}}=9.5 \mathrm{~Hz}, 1 \mathrm{H}\right.$, $\left.2^{\prime}-\mathrm{H}\right), 5.40\left(\mathrm{t}, J_{2^{\prime}, 3^{\prime}}=J_{3^{\prime}, 4^{\prime}}=9.2 \mathrm{~Hz}, 1 \mathrm{H}, 3^{\prime}-\mathrm{H}\right), 5.10\left(\mathrm{dd}, J_{4^{\prime}, 5^{\prime}}=10.1\right.$, $\left.J_{3^{\prime}, 4^{\prime}}=9.2 \mathrm{~Hz}, 1 \mathrm{H}, 4^{\prime}-\mathrm{H}\right), 5.07$ (d, $\left.J_{1,2}=3.5 \mathrm{~Hz}, 1 \mathrm{H}, 1-\mathrm{H}\right), 4.91$ (d, $\left.=11.9 \mathrm{~Hz}, 1 \mathrm{H}, \mathrm{OCH}_{2} \mathrm{Ph}\right), 4.67\left(\mathrm{dt}, J_{2,3 \mathrm{~b}}=12.7, J_{1,2}=J_{2,3 \mathrm{a}}=4.0 \mathrm{~Hz}\right.$, $1 \mathrm{H}, 2-\mathrm{H}), 4.62\left(\mathrm{~d}, J=11.9 \mathrm{~Hz}, 1 \mathrm{H}, \mathrm{OCH}_{2} \mathrm{Ph}\right), 4.56\left(\mathrm{~d}, J_{1^{\prime}, 2^{\prime}}=\right.$ $\left.9.7 \mathrm{~Hz}, 1 \mathrm{H}, 1^{\prime}-\mathrm{H}\right), 4.55\left(\mathrm{dt}, J_{5,6 \mathrm{a}}=8.7, J_{4,5}=J_{5,6 \mathrm{~b}}=1.8 \mathrm{~Hz}, 1 \mathrm{H}, 5-\right.$ $\mathrm{H}), 4.21\left(\mathrm{dd}, J_{6^{\prime} \mathrm{a}, 6^{\prime} \mathrm{b}}=12.5, J_{5^{\prime}, 6^{\prime} \mathrm{a}}=3.0 \mathrm{~Hz}, 1 \mathrm{H}, 6^{\prime} \mathrm{a}-\mathrm{H}\right), 4.18$ (dd, $\left.J_{6^{\prime} \mathrm{a}, 6^{\prime} \mathrm{b}}=12.5, J_{5^{\prime}, 6^{\prime} \mathrm{b}}=5.6 \mathrm{~Hz}, 1 \mathrm{H}, 6^{\prime} \mathrm{b}-\mathrm{H}\right), 4.02\left(\mathrm{dd}, J_{6 \mathrm{a}, 6 \mathrm{~b}}=11.9\right.$, $\left.J_{5,6 \mathrm{a}}=8.9 \mathrm{~Hz}, 1 \mathrm{H}, 6 \mathrm{a}-\mathrm{H}\right), 3.86\left(\mathrm{dd}, J_{6 \mathrm{a}, 6 \mathrm{~b}}=11.9, J_{5,6 \mathrm{~b}}=2.0 \mathrm{~Hz}, 1 \mathrm{H}\right.$, $6 \mathrm{~b}-\mathrm{H}), 3.80\left(\mathrm{ddd}, J_{4^{\prime}, 5^{\prime}}=10.1, J_{5^{\prime}, 6^{\prime} \mathrm{b}}=5.5, J_{5^{\prime}, 6^{\prime} \mathrm{a}}=2.9 \mathrm{~Hz}, 1 \mathrm{H}, 5^{\prime}-\right.$ $\mathrm{H}), 3.53$ (br. S, $1 \mathrm{H}, \mathrm{H}-4), 2.36\left(\mathrm{td}, J_{2,3 \mathrm{a}}=J_{3 \mathrm{a}, 3 \mathrm{~b}}=13.5, J_{3 \mathrm{a}, 4}=\right.$ $4.0 \mathrm{~Hz}, 1 \mathrm{H}, 3 \mathrm{a}-\mathrm{H}), 2.08(\times 2), 2.05,2.04,2.02\left(5 \mathrm{~s}, 16 \mathrm{H}, \mathrm{CH}_{3} \mathrm{CO}\right.$ overlapping with $3 \mathrm{~b}-\mathrm{H}), 0.90\left(\mathrm{~s}, 9 \mathrm{H}, \mathrm{Si}\left(\mathrm{CH}_{3}\right)_{2} \mathrm{C}\left(\mathrm{CH}_{3}\right)_{3}\right), 0.09,0.07$ (2 s, 6H, Si $\left(\mathrm{CH}_{3}\right)_{2} \mathrm{C}\left(\mathrm{CH}_{3}\right)_{3}$ ) ppm. $\left.{ }^{13} \mathrm{C} \mathrm{NMR} \mathrm{(125.7} \mathrm{MHz,} \mathrm{CDCl}_{3}\right)$ : $\delta=170.8,170.5(\times 2), 169.3,168.9\left(\mathrm{COCH}_{3}\right), 137.1,128.6,128.3$, 128.1 (C-aromatic), 94.5 (C-1), 86.6 (C-1'), $77.4\left(\mathrm{C}-5^{\prime}\right), 74.1\left(\mathrm{C}-3^{\prime}\right)$, 72.7 (C-5), $68.7\left(\mathrm{OCH}_{2} \mathrm{Ph}\right), 68.0\left(\mathrm{C}-4^{\prime}\right), 67.4(\mathrm{C}-2), 66.4\left(\mathrm{C}-2^{\prime}\right), 64.3$ (C-6), 62.2 (C-6'), 59.4 (C-4), $26.2(\mathrm{C}-3), 26.1\left(\mathrm{Si}\left(\mathrm{CH}_{3}\right)_{2} \mathrm{C}\left(\mathrm{CH}_{3}\right)_{3}\right)$,

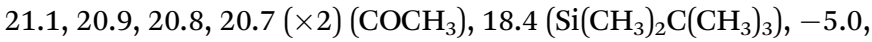
$-5.2\left(\mathrm{Si}\left(\mathrm{CH}_{3}\right)_{2} \mathrm{C}\left(\mathrm{CH}_{3}\right)_{3}\right)$ ppm. HRMS (ESI): calcd for $\mathrm{C}_{35} \mathrm{H}_{52}-$ $\mathrm{NaO}_{15} \mathrm{SSi} 795.2688[\mathrm{M}+\mathrm{Na}]^{+}$; found 795.2699.

Benzyl 2-O-acetyl-3-deoxy-6-O-(tert-butyldimethylsilyl)-4-S$(2,3,4,6$-tetra- $O$-acetyl- $\beta$-D-glucopyranosyl)-4-thio- $\alpha$-D-xylo-hexopyranoside $(\boldsymbol{S})-\boldsymbol{S}$-oxide $(\mathbf{1 6 S})$. The minor product of the oxidation of compound 13 was the white solid sulfoxide $16 S(31 \mathrm{mg}$, $37 \%$ ), $\mathrm{mp}$ at $118.1{ }^{\circ} \mathrm{C}$ (dec.). $R_{\mathrm{f}}=0.30, \mathrm{CH}_{2} \mathrm{Cl}_{2} / \mathrm{EtOAc}(4: 1)$. $[\alpha]_{\mathrm{D}}^{25}=+31.1\left(c=0.7, \mathrm{CHCl}_{3}\right) .{ }^{1} \mathrm{H}$ NMR $\left(500 \mathrm{MHz}, \mathrm{CDCl}_{3}\right): \delta=$ 7.38-7.28 (m, 5H, $\left.\mathrm{PhCH}_{2} \mathrm{O}\right), 5.49\left(\mathrm{t}, J_{1^{\prime}, 2^{\prime}}=J_{2^{\prime}, 3^{\prime}}=9.5 \mathrm{~Hz}, 1 \mathrm{H}, 2^{\prime}-\right.$ $\mathrm{H}), 5.28\left(\mathrm{t}, J_{2^{\prime}, 3^{\prime}}=J_{3^{\prime}, 4^{\prime}}=9.3 \mathrm{~Hz}, 1 \mathrm{H}, 3^{\prime}-\mathrm{H}\right), 5.20\left(\mathrm{~d}, J_{1,2}=2.8 \mathrm{~Hz}\right.$, $1 \mathrm{H}, 1-\mathrm{H}), 5.18(\mathrm{~m}, 1 \mathrm{H}, 2-\mathrm{H}), 5.09\left(\mathrm{dd}, J_{4^{\prime}, 5^{\prime}}=10.0, J_{3^{\prime}, 4^{\prime}}=9.5 \mathrm{~Hz}\right.$, $\left.1 \mathrm{H}, 4^{\prime}-\mathrm{H}\right), 4.72\left(\mathrm{~d}, J=12.1 \mathrm{~Hz}, 1 \mathrm{H}, \mathrm{OCH}_{2} \mathrm{Ph}\right), 4.59\left(\mathrm{~d}, J_{1^{\prime}, 2^{\prime}}=\right.$ $\left.9.7 \mathrm{~Hz}, 1 \mathrm{H}, 1^{\prime}-\mathrm{H}\right), 4.56$ (d, J = $\left.12.1 \mathrm{~Hz}, 1 \mathrm{H}, \mathrm{OCH}_{2} \mathrm{Ph}\right), 4.32$ (td, $\left.J_{5,6 \mathrm{a}}=J_{5,6 \mathrm{~b}}=6.6, J_{4,5}=2.6 \mathrm{~Hz}, 1 \mathrm{H}, 5-\mathrm{H}\right), 4.22\left(\mathrm{dd}, J_{6^{\prime} \mathrm{a}, 6^{\prime} \mathrm{b}}=12.6\right.$, $\left.J_{5^{\prime}, 6^{\prime} \mathrm{a}}=4.9 \mathrm{~Hz}, 1 \mathrm{H}, 6^{\prime} \mathrm{a}-\mathrm{H}\right), 4.13\left(\mathrm{dd}, J_{6^{\prime} \mathrm{a}, 6^{\prime} \mathrm{b}}=12.6, J_{5^{\prime}, 6^{\prime} \mathrm{b}}=2.2 \mathrm{~Hz}\right.$, $\left.1 \mathrm{H}, 6^{\prime} \mathrm{b}-\mathrm{H}\right), 3.74\left(\mathrm{ddd}, J_{4^{\prime}, 5^{\prime}}=10.0, J_{5^{\prime}, 6^{\prime} \mathrm{a}}=4.9, J_{5^{\prime}, 6^{\prime} \mathrm{b}}=2.3 \mathrm{~Hz}\right.$, $\left.1 \mathrm{H}, 5^{\prime}-\mathrm{H}\right), 3.72(\mathrm{~m}, 2 \mathrm{H}, 6 \mathrm{a}-\mathrm{H}, 6 \mathrm{~b}-\mathrm{H}), 3.57\left(\mathrm{dt}, J_{3 \mathrm{~b}, 4}=5.0, J_{3 \mathrm{a}, 4}=\right.$ $\left.J_{4,5}=2.5 \mathrm{~Hz}, 1 \mathrm{H}, 4-\mathrm{H}\right), 2.40\left(\mathrm{ddd}, J_{3 \mathrm{a}, 3 \mathrm{~b}}=13.2, J_{2,3 \mathrm{a}}=5.1, J_{3 \mathrm{a}, 4}=\right.$ $2.5 \mathrm{~Hz}, 1 \mathrm{H}, 3 \mathrm{a}-\mathrm{H}), 2.24\left(\mathrm{ddd}, J_{3 \mathrm{a}, 3 \mathrm{~b}}=13.5, J_{2,3 \mathrm{~b}}=11.6, J_{3 \mathrm{~b}, 4}=\right.$ $5.4 \mathrm{~Hz}, 1 \mathrm{H}, 3 \mathrm{~b}-\mathrm{H}), 2.07,2.03,2.02(\times 2), 2.01\left(\mathrm{COCH}_{3}\right), 0.92(\mathrm{~s}$, $\left.9 \mathrm{H}, \mathrm{Si}\left(\mathrm{CH}_{3}\right)_{2} \mathrm{C}\left(\mathrm{CH}_{3}\right)_{3}\right), 0.10(\times 2)\left(2 \mathrm{~s}, 6 \mathrm{H}, \mathrm{Si}\left(\mathrm{CH}_{3}\right)_{2} \mathrm{C}\left(\mathrm{CH}_{3}\right)_{3}\right) \mathrm{ppm}$.
${ }^{13} \mathrm{C}$ NMR (125.7 MHz, $\left.\mathrm{CDCl}_{3}\right): \delta=170.6,170.4,170.0,169.3$, $168.9\left(\mathrm{COCH}_{3}\right), 137.5,128.6,128.1,128.0$ (C-aromatic), 95.2 (C1), $90.7\left(\mathrm{C}-1^{\prime}\right), 77.0\left(\mathrm{C}-5^{\prime}\right), 73.9\left(\mathrm{C}-3^{\prime}\right), 70.0\left(\mathrm{OCH}_{2} \mathrm{Ph}\right), 68.2(\mathrm{C}-5)$, $67.7\left(\mathrm{C}-2^{\prime}\right), 67.6\left(\mathrm{C}-4^{\prime}\right), 66.8\left(\mathrm{C}-2^{\prime}\right), 62.2(\mathrm{C}-6), 61.8\left(\mathrm{C}-6^{\prime}\right), 53.7$ (C4), $26.0\left(\mathrm{Si}\left(\mathrm{CH}_{3}\right)_{2} \mathrm{C}\left(\mathrm{CH}_{3}\right)_{3}\right), 22.7(\mathrm{C}-3), 21.0,20.8(\times 2), 20.7(\times 2)$ $\left(\mathrm{COCH}_{3}\right), 18.4\left(\mathrm{Si}\left(\mathrm{CH}_{3}\right)_{2} \mathrm{C}\left(\mathrm{CH}_{3}\right)_{3}\right),-5.2(\times 2)\left(\mathrm{Si}\left(\mathrm{CH}_{3}\right)_{2} \mathrm{C}\left(\mathrm{CH}_{3}\right)_{3}\right)-$ ppm. HRMS (ESI): calcd for $\mathrm{C}_{35} \mathrm{H}_{52} \mathrm{NaO}_{15} \mathrm{SSi} 795.2688[\mathrm{M}+\mathrm{Na}]^{+}$; found 795.2705 .

Benzyl 2-O-acetyl-3-deoxy-4-S-(2,3,4,6-tetra- $O$-acetyl- $\beta$-D-glucopyranosyl)-4-thio- $\alpha$-D-xylo-hexopyranoside $(R)-S$-oxide (17R). The product of the oxidation of thiodisaccharide 14 was the sulfoxide $17 \boldsymbol{R}$ (43 $\mathrm{mg}, 80 \%$ ) obtained as a white solid, $\mathrm{mp}$ at $158.1^{\circ} \mathrm{C}$ (dec.). $R_{\mathrm{f}}=0.34$, pentane/EtOAc $(3: 1) \cdot[\alpha]_{\mathrm{D}}^{22}=+4.0(c=$ 0.8, $\mathrm{CHCl}_{3}$ ). ${ }^{1} \mathrm{H}$ NMR (400 MHz, $\left.\mathrm{CDCl}_{3}\right) \delta=7.37-7.29(\mathrm{~m}, 5 \mathrm{H}$, $\left.\mathrm{PhCH}_{2} \mathrm{O}\right), 5.50\left(\mathrm{t}, J_{1^{\prime}, 2^{\prime}}=J_{2^{\prime}, 3^{\prime}}=9.5 \mathrm{~Hz}, 1 \mathrm{H}, 2^{\prime}-\mathrm{H}\right), 5.41\left(\mathrm{t}, J_{2^{\prime}, 3^{\prime}}=\right.$ $\left.J_{3^{\prime}, 4^{\prime}}=9.3 \mathrm{~Hz}, 1 \mathrm{H}, 3^{\prime}-\mathrm{H}\right), 5.12\left(\mathrm{t}, J_{3^{\prime}, 4^{\prime}}=J_{4^{\prime}, 5^{\prime}}=9.7 \mathrm{~Hz}, 1 \mathrm{H}, 4^{\prime}-\mathrm{H}\right)$, $5.04\left(\mathrm{~d}, J_{1,2}=3.1 \mathrm{~Hz}, 1 \mathrm{H}, 1-\mathrm{H}\right), 4.77(\mathrm{~d}, J=12.1 \mathrm{~Hz}, 1 \mathrm{H}$, $\mathrm{PhCH}_{2} \mathrm{O}$ ), 4.65 (d, $\left.J=12.2 \mathrm{~Hz}, 1 \mathrm{H}, \mathrm{PhCH}_{2} \mathrm{O}\right), 4.61$ (d, $J_{1^{\prime}, 2^{\prime}}=$ $\left.9.7 \mathrm{~Hz}, 1 \mathrm{H}, 1^{\prime}-\mathrm{H}\right), 4.60$ (m, 1H, 2-H), 4.50 (m, 1H, 5-H), 4.24 (dd, $\left.J_{6^{\prime} \mathrm{a}, 6^{\prime} \mathrm{b}}=12.3, J_{5^{\prime}, 6^{\prime} \mathrm{a}}=1.3 \mathrm{~Hz}, 1 \mathrm{H}, 6^{\prime} \mathrm{a}-\mathrm{H}\right), 4.16\left(\mathrm{dd}, J_{6^{\prime} \mathrm{a}, 6^{\prime} \mathrm{b}}=12.4\right.$, $\left.J_{5^{\prime}, 6^{\prime} \mathrm{b}}=5.6 \mathrm{~Hz}, 1 \mathrm{H}, 6^{\prime} \mathrm{b}-\mathrm{H}\right), 3.81\left(\mathrm{~m}, 2 \mathrm{H}, 6 \mathrm{a}-\mathrm{H}, 5^{\prime}-\mathrm{H}\right), 3.74(\mathrm{~m}, 2 \mathrm{H}$, $4-\mathrm{H}, 6 \mathrm{~b}-\mathrm{H}), 2.37\left(\mathrm{td}, J_{3 \mathrm{a}, 3 \mathrm{~b}}=13.9, J_{2,3 \mathrm{a}}=3.8 \mathrm{~Hz}, 1 \mathrm{H}, 3 \mathrm{a}-\mathrm{H}\right), 2.08$ $(\times 2), 2.06,2.04,2.02\left(5 \mathrm{~s}, 16 \mathrm{H}, \mathrm{CH}_{3} \mathrm{CO}\right.$ overlapping with $\left.3 \mathrm{~b}-\mathrm{H}\right)$. ${ }^{13} \mathrm{C} \mathrm{NMR}\left(\mathrm{CDCl}_{3}, 100.0 \mathrm{MHz}\right) \delta=170.8,170.5,170.4,169.3$, $168.9\left(\mathrm{COCH}_{3}\right), 137.1,128.7,128.3,128.2$ (C-aromatic), 95.3 (C1), $86.5\left(\mathrm{C}-1^{\prime}\right), 77.4\left(\mathrm{C}-5^{\prime}\right), 74.0\left(\mathrm{C}-3^{\prime}\right), 70.3\left(\mathrm{PhCH}_{2} \mathrm{O}\right), 69.5(\mathrm{C}-5)$, $68.0\left(\mathrm{C}-4^{\prime}\right), 67.7$ (C-2), 66.2 (C-2'), $62.0(\mathrm{C}-6), 61.8$ (C-6'), 58.9 (C4), 25.4 (C-3), 21.1, 20.8, $20.7(\times 2), 20.6\left(\mathrm{COCH}_{3}\right)$ ppm. HRMS (ESI): calcd for $\mathrm{C}_{29} \mathrm{H}_{38} \mathrm{NaO}_{15} \mathrm{~S} 681.1824[\mathrm{M}+\mathrm{Na}]^{+}$; found 681.1830 .

Benzyl 3-deoxy-4-S-( $\beta$-D-glucopyranosyl)-4-thio- $\alpha$-D-xylohexopyranoside $(\boldsymbol{R})$ - $S$-oxide $(\mathbf{1 8 R})$. A solution of the thiodisaccharide $S$-oxide $17 R\left(49 \mathrm{mg}, 0.074 \mathrm{mmol}\right.$ ) in $\mathrm{MeOH} / \mathrm{Et}_{3} \mathrm{~N} /$ $\mathrm{H}_{2} \mathrm{O}(4: 1: 5 ; 0.46 \mathrm{~mL})$ was stirred at room temperature for $3 \mathrm{~h}$. The mixture was concentrated, and the resulting residue was dissolved in water $(1 \mathrm{~mL})$ and eluted through a column filled with a Dowex MR-3C mixed-bed ion-exchange resin. The deionized solution was concentrated, and the unprotected compound was purified by dissolution in water $(1 \mathrm{~mL})$ and filtration through an octadecyl C18 minicolumn (Amprep, Amersham Biosciences). Evaporation of the water gave the unprotected thiodisaccharide $S$-oxides as colourless syrupy that was identified as $18 R(31 \mathrm{mg}, 93 \%) . R_{\mathrm{f}}=0.72, \mathrm{BuOH} / \mathrm{EtOH} / \mathrm{H}_{2} \mathrm{O}$ $(10: 4: 4) .[\alpha]_{\mathrm{D}}^{23}=+32.3(c=1.0, \mathrm{MeOH}) .{ }^{1} \mathrm{H}$ NMR $(400 \mathrm{MHz}$, $\left.\mathrm{D}_{2} \mathrm{O}\right) \delta=7.51-7.40\left(\mathrm{~m}, 5 \mathrm{H}, \mathrm{PhCH}_{2} \mathrm{O}\right), 5.10\left(\mathrm{~d}, J_{1,2}=3.3 \mathrm{~Hz}, 1 \mathrm{H}\right.$, $1-\mathrm{H}), 4.88$ (d, $\left.J=11.6 \mathrm{~Hz}, 1 \mathrm{H}, \mathrm{PhCH}_{2} \mathrm{O}\right), 4.69$ (d, $J=11.7 \mathrm{~Hz}, 1 \mathrm{H}$, $\left.\mathrm{PhCH}_{2} \mathrm{O}\right), 4.56(\mathrm{~m}, 1 \mathrm{H}, 5-\mathrm{H}), 4.50$ (d, $\left.J_{1^{\prime}, 2^{\prime}}=9.2 \mathrm{~Hz}, 1 \mathrm{H}, 1^{\prime}-\mathrm{H}\right)$, 3.96-3.89 (m, 3H, 2-H, 6'a-H, 6' b-H), 3.84 (m, 2H, 4-H, 6a-H), $3.76\left(\mathrm{~m}, 2 \mathrm{H}, 6 \mathrm{~b}-\mathrm{H}, 2^{\prime}-\mathrm{H}\right), 3.69\left(\mathrm{t}, J_{2^{\prime}, 3^{\prime}}=J_{3^{\prime}, 4^{\prime}}=8.8 \mathrm{~Hz}, 1 \mathrm{H}, 3^{\prime}-\right.$ $\mathrm{H}), 3.66\left(\mathrm{~m}, 1 \mathrm{H}, 5^{\prime}-\mathrm{H}\right), 3.50\left(\mathrm{t}, J_{3^{\prime}, 4^{\prime}}=J_{4^{\prime}, 5^{\prime}}=9.3 \mathrm{~Hz}, 1 \mathrm{H}, 4^{\prime}-\mathrm{H}\right)$, $2.30\left(\mathrm{td}, J_{2,3 \mathrm{a}}=J_{3 \mathrm{a}, 3 \mathrm{~b}}=14.3, J_{3 \mathrm{a}, 4}=3.9 \mathrm{~Hz}, 1 \mathrm{H}, 3 \mathrm{a}-\mathrm{H}\right) 1.96(\mathrm{br} \mathrm{dt}$, $\left.J_{3 \mathrm{a}, 3 \mathrm{~b}}=14.2, J_{2,3 \mathrm{~b}}=J_{3 \mathrm{~b}, 4}=3.5 \mathrm{~Hz}, 1 \mathrm{H}, 3 \mathrm{~b}-\mathrm{H}\right) \mathrm{ppm} .{ }^{13} \mathrm{C} \mathrm{NMR}$ $\left(\mathrm{CDCl}_{3}, 100.0 \mathrm{MHz}\right) \delta=136.9,128.8,128.6,128.4$ (C-aromatic), 97.1 (C-1), $87.2\left(\mathrm{C}-1^{\prime}\right), 80.5\left(\mathrm{C}-5^{\prime}\right), 76.8\left(\mathrm{C}-3^{\prime}\right), 71.2(\mathrm{C}-5), 69.6$ $\left.\left(\mathrm{PhCH}_{2} \mathrm{O}\right), 68.6\left(\mathrm{C}^{\prime}\right)^{\prime}\right), 67.2\left(\mathrm{C}-2^{\prime}\right), 63.6(\mathrm{C}-2), 62.0(\mathrm{C}-6), 60.5(\mathrm{C}-$ $\left.6^{\prime}\right), 56.7$ (C-4), 27.9 (C-3) ppm. HRMS (ESI): calcd for $\mathrm{C}_{19} \mathrm{H}_{28} \mathrm{NaO}_{10} \mathrm{~S} 471.1295[\mathrm{M}+\mathrm{Na}]^{+}$; found 471.1275. 


\section{Conflicts of interest}

There are no conflicts of interest to declare.

\section{Acknowledgements}

The authors are indebted to the Secretaría de Ciencia $y$ Tecnología (SECyT), Universidad Nacional de Córdoba (UNC), Universidad de Buenos Aires (UBA), Consejo Nacional de Investigaciones Científicas y Técnicas (CONICET) and Fondo para la investigación Científica y Tecnológica Argentina (FONСуT) for financial support. J. P. C., A. B. P. and O. V. are research members from CONICET.

\section{Notes and references}

1 A. Tarozzi, C. Angeloni, M. Malaguti, F. Morroni, S. Hrelia and P. Hrelia, Oxid. Med. Cell. Longevity, 2013, 415078.

2 J. Li, J. Zhao, J. E. Hamer-Maansson, T. Andersson, R. Fulmer, M. Illueca and P. Lundborg, Clin. Ther., 2006, 28, 419-427.

3 M. Darwish, M. Kirby, E. T. Hellriegel and P. Robertson Jr, Clin. Drug Invest., 2009, 29, 613-623.

4 S. Otocka, M. Kwiatkowska, L. Madalińska and P. Kiełbasiński, Chem. Rev., 2017, 117, 4147-4181.

5 N. Khiar, A. Salvador, V. Valdivia, A. Chelouan, A. Alcudia, E. Álvarez and I. Fernández, J. Org. Chem., 2013, 78, 65106521.

6 H. Pellissier, Tetrahedron, 2006, 62, 5559-5601.

7 M. C. Carreño, Chem. Rev., 1995, 95, 1717-1760.

8 F. Zhong, A. Pçthig and T. Bach, Chem. - Eur. J., 2015, 21, 10310-10313.

9 Z. Z. Li, S. U. Yao and B. H. Ye, ChemPlusChem, 2015, 80, 141150.

10 A. A. Elkina, T. I. Kylosova, V. V. Grishko and I. B. Ivshina, J. Mol. Catal. B: Enzym., 2013, 89, 82-85.

11 I. Fernández and N. Khiar, Chem. Rev., 2003, 103, 3651-3705.

12 N. Khiar, I. Alonso, N. Rodriguez, A. Fernandez-Mayoralas, J. Jimenez-Barbero, O. Nieto, F. Cano, C. Foces-Foces and M. Martin-Lomas, Tetrahedron Lett., 1997, 38, 8267-8270.

13 N. Khiar, I. Fernández, C. S. Araújo, J. A. Rodríguez, B. Suárez and E. Álvarez, J. Org. Chem., 2003, 68, 1433-1442.

14 Z. J. Witczak, P. Kaplon and P. M. Dey, Carbohydr. Res., 2003, 338, 11-18.

15 E. Repetto, C. Marino and O. Varela, Bioorg. Med. Chem., 2013, 21, 3327-3333.

16 V. E. Manzano, M. L. Uhrig and O. Varela, Org. Biomol. Chem., 2012, 10, 8884-8894.

17 A. J. Cagnoni, M. L. Uhrig and O. Varela, Bioorg. Med. Chem., 2009, 17, 6203-6212.

18 V. E. Manzano, M. L. Uhrig and O. Varela, J. Org. Chem., 2008, 7224-7235.
19 M. L. Uhrig, V. E. Manzano and O. Varela, Eur. J. Org. Chem., 2006, 162-168.

20 J. P. Colomer, M. Á. Canales Mayordomo, B. Fernández de Toro, J. Jiménez-Barbero and O. Varela, Eur. J. Org. Chem., 2015, 1448-1455.

21 J. P. Colomer, V. E. Manzano and O. Varela, Eur. J. Org. Chem., 2013, 7343-7353.

22 C. A. Sanhueza, A. C. Arias, R. L. Dorta and J. T. Vázquez, Tetrahedron: Asymmetry, 2010, 21, 1830-1832.

23 C. A. Sanhueza, R. L. Dorta and J. T. Vázquez, J. Org. Chem., 2011, 76, 7769-7780.

24 C. A. Sanhueza, R. L. Dorta and J. T. Vázquez, Tetrahedron: Asymmetry, 2013, 24, 582-593.

25 J. P. Colomer, B. Fernández de Toro, F. J. Cañada, F. Corzana, J. Jiménez-Barbero, A. Canales and O. Varela, Eur. J. Org. Chem., 2016, 5117-5122.

26 M. L. Uhrig and O. Varela, Aust. J. Chem., 2002, 55, 155-160. 27 C. J. Salomon, E. G. Mata and O. A. Mascaretti, Tetrahedron Lett., 1991, 32, 4239-4242.

28 N. Floyd, B. Vijayakrishnan, J. R. Koeppe and B. G. Davis, Angew. Chem., Int. Ed., 2009, 48, 7798-7802.

29 W. G. Dauben, B. A. Kowalczyk and F. W. Lichtenthaler, J. Org. Chem., 1990, 55, 2391-2398.

30 F. W. Lichtenthaler, S. Nishiyama, P. Kohler and H. J. Lindner, Carbohydr. Res., 1985, 136, 13-26.

31 D. Crich, J. Mataka, L. N. Zakharov, A. L. Rheingold and D. J. Wink, J. Am. Chem. Soc., 2002, 124, 6028-6036, and references therein.

32 L. Calle, V. Roldós, F. J. Cañada, M. L. Uhrig, A. J. Cagnoni, V. E. Manzano, O. Varela and J. Jiménez-Barbero, Chem. Eur. J., 2013, 19, 4262-4270.

33 E. Montero, A. García-Herrero, J. L. Asensio, K. Hirai, S. Ogawa, F. Santoyo-González, F. J. Cañada and J. Jiménez-Barbero, Eur. J. Org. Chem., 2000, 1945-1952.

34 A. García-Herrero, E. Montero, J. L. Muñoz, J. F. Espinosa, A. Vián, J. L. García, J. L. Asensio, F. J. Cañada and J. Jiménez-Barbero, J. Am. Chem. Soc., 2002, 124, 4804-4810.

35 D. G. H. C. H. Green, J. Chem. Soc., Perkin Trans. 2, 1972, 458463.

36 R. D. G. Cooper, P. V. DeMarco, J. C. Cheng and N. D. Jones, J. Am. Chem. Soc., 1969, 91, 1408-1415.

37 R. D. G. Cooper, P. V. DeMarco and D. O. Spry, J. Am. Chem. Soc., 1969, 91, 1528-1529.

38 D. H. R. Barton, F. Comer and P. G. Sammes, J. Am. Chem. Soc., 1969, 91, 1529-1530.

39 N. Khiar, Tetrahedron Lett., 2000, 41, 9059-9063.

40 H. B. Henbest and R. A. L. Wilson, J. Chem. Soc., 1957, 19581965.

41 P. Chamberlain, M. L. Roberts and G. H. Whitham, J. Chem. Soc. B, 1970, 1374-1381. 